\title{
Biodegradable and Biocompatible Systems Based on Hydroxyapatite Nanoparticles
}

\author{
Pau Turon ${ }^{1, *}$, Luís J. del Valle ${ }^{2}$, Carlos Alemán ${ }^{2, *}$ and Jordi Puiggalí ${ }^{2, *}$ \\ 1 B. Braun Surgical S.A., Carretera de Terrassa 121, Rubí 08191, Spain \\ 2 Chemical Engineering Department, Escola d'Enginyeria de Barcelona Est-EEBE, c/Eduard Maristany 10-14, \\ Barcelona 08019, Spain; luis.javier.del.valle@upc.edu \\ * Correspondence: pau.turon@bbraun.com (P.T.); carlos.aleman@upc.edu (C.A.); Jordi.Puiggali@upc.edu (J.P.); \\ Tel.: +34-93-401-6684 (P.T.); +34-93-401-0883 (C.A.); +34-93-401-5649 (J.P.)
}

Academic Editor: Patrick A. Fairclough

Received: 7 November 2016; Accepted: 23 December 2016; Published: 6 January 2017

\begin{abstract}
Composites of hydroxyapatite (HAp) are widely employed in biomedical applications due to their biocompatibility, bioactivity and osteoconductivity properties. In fact, the development of industrially scalable hybrids at low cost and high efficiency has a great impact, for example, on bone tissue engineering applications and even as drug delivery systems. New nanocomposites constituted by HAp nanoparticles and synthetic or natural polymers with biodegradable and biocompatible characteristics have constantly been developed and extensive works have been published concerning their applications. The present review is mainly focused on both the capability of HAp nanoparticles to encapsulate diverse compounds as well as the preparation methods of scaffolds incorporating HAp. Attention has also been paid to the recent developments on antimicrobial scaffolds, bioactive membranes, magnetic scaffolds, in vivo imaging systems, hydrogels and coatings that made use of HAp nanoparticles.
\end{abstract}

Keywords: nanoparticles; hydroxyapatite; drug delivery; scaffolds; non-viral vectors

\section{Introduction}

Hydroxyapatite (HAp, $\left.\mathrm{Ca}_{10}\left(\mathrm{PO}_{4}\right)_{6}(\mathrm{OH})_{2}\right)$ is the main inorganic constituent of bone and teeth and therefore has been extensively studied as an artificial bone substitute [1,2]. Moreover, composites prepared from synthetic HAp and collagen have a great potential to mimic and replace skeletal bones. Biomedical applications of calcium phosphate (CaP) based scaffolds take for example advantage of their ability to induce bone formation and vascularization and to cover varied uses such as bone augmentations, artificial bone grafts, maxillofacial reconstruction, spinal fusion, periodontal disease repairs and bone fillers after tumor surgery [2]. In fact, reconstructive tissue engineering is nowadays a highly active research area that involves the development of materials with outstanding properties. These can only be achieved by means of combining different components, processes and technologies. Scaffolds constituted by biodegradable polymers and HAp nanoparticles have a great potential due to the excellent combination of properties (e.g., enhancement of biocompatibility and reinforcing effect provided by the inorganic component) and the facility of preparation.

Researches are nowadays extensively involved in the study of bionanocomposites based on HAp nanoparticles due to both their recognized applications in the biomedical field and their high potential for new specific uses [3]. In this way, development of new processing technologies, surface treatments, encapsulation techniques or incorporation of compatibilizers are topics that have made great progress in recent years and deserve special attention. The successful combination of desired properties of matrix polymers with those of fillers should lead to innovative materials having both appropriate in vitro and in vivo properties for their use in the biomedical field [4]. HAp bionanocomposites can be obtained 
following different processes that are able to provide specific features for a specific purpose but, unfortunately, none of them can cover all possible requirements. Thus, materials that can be applied for example in tissue engineering should fulfill a wide range of specifications: degradation products must be biocompatible and non-toxic, the scaffold should have a 3D porous geometry, good mechanical properties and should provide an appropriate microenvironment for cells regenerating the tissue, supporting cell attachment, proliferation, differentiation, and neo tissue genesis [5].

The present review is a survey of recent works concerning hydroxyapatite nanocomposites, being organized in sections that firstly deal with preparation methods of nanoparticles and derived biocomposites with applications in tissue engineering. Secondly, the modification/encapsulation techniques that provide functional bionanocomposites are considered. Specifically, the development of bionanocomposites with antimicrobial properties, doping with biomarkers for imaging and medical diagnosis, and finally encapsulation/adsorption of transfecting agents, proteins and drugs are mentioned [6,7]. HAp has been revealed as a highly promising system for new therapies that take advantage of the capability of HAp to mask biomolecules, cross biological barriers and deliver drugs just onto the disease target.

\section{Preparation of HAp Nanoparticles}

CaPs can be found in different individual phases (e.g., amorphous calcium phosphate (ACP), tricalcium phosphate (TCP), tetracalcium phosphate (TTCP), brushite (B), monetite (M), octacalcium phosphate (OCP) and hydroxyapatite (HAp)) that differ on crystalline structure, composition and $\mathrm{Ca} / \mathrm{P}$ ratio (e.g., calcium-deficient HAp), degree of substitution (e.g., carbonate-substituted HAp) and properties (e.g., solubility and bioresorbability). Nevertheless, none of these phases can be considered as an ideal material and consequently the development of multiphasic systems is gaining attention [8].

In any case, HAp is the most stable and less soluble calcium orthophosphate, being its structure defined by a monoclinic $P 2_{1} / b$ space group $\left(a=0.984 \mathrm{~nm}, b=2 a, c=0.688 \mathrm{~nm}\right.$ and $\left.\gamma=120^{\circ}\right)$, although at high temperatures (ca. $250{ }^{\circ} \mathrm{C}$ ) converts to a hexagonal $P 6_{3} / \mathrm{m}$ space group a $(a=b=0.943 \mathrm{~nm}$, $c=0.689 \mathrm{~nm}$ and $\left.\gamma=120^{\circ}\right)[9,10]$.

Porous HAp particles can be prepared according to a great diversity of methods [11] such as self-assembly [12-15], spray drying [16], double emulsion [17], solvothermal [18], sol-gel [19] and hydrothermal [20-23].

In general, the most widely used methods are based on chemical precipitation routes according to any of the following chemical reactions:

$$
\begin{gathered}
10 \mathrm{Ca}(\mathrm{OH})_{2}+6 \mathrm{H}_{3} \mathrm{PO}_{4} \rightarrow \mathrm{Ca}_{10}\left(\mathrm{PO}_{4}\right)_{6}(\mathrm{OH})_{2}+18 \mathrm{H}_{2} \mathrm{O} \\
10 \mathrm{Ca}\left(\mathrm{NO}_{3}\right)_{2}+6\left(\mathrm{NH}_{4}\right)_{2} \mathrm{HPO}_{4}+2 \mathrm{H}_{2} \mathrm{O} \rightarrow \mathrm{Ca}_{10}\left(\mathrm{PO}_{4}\right)_{6}(\mathrm{OH})_{2}+12 \mathrm{NH}_{4} \mathrm{NO}_{3}+8 \mathrm{HNO}_{3}
\end{gathered}
$$

Despite the high simplicity of nanoprecipitation, a great control over morphology and size can be achieved by modification of experimental conditions [24-26] and the addition of surfactants [27] (e.g., stearic acid, monosaccharides and cetyltrimethylammonium bromide (CTAB)) and chelating agents $[28,29]$ (e.g., trisodium citrate and potassium sodium tartrate). Thus, the way reactants are mixed, the solvents that are employed or the $\mathrm{pH}$ conditions play a fundamental role on the final structure and morphology. For example, a rapid mixing of reactant solutions firstly leads to amorphous calcium phosphate [24], which after thermal treatment converts to a crystalline phase [25]. In addition, it is well-known that high and low $\mathrm{pHs}$ tend to form isotropic and anisotropic particles, respectively [26].

Self-assembly using a soft template approach is another simple method that is receiving great attention. In this case, the control of pore size can be undertaken by selection of co-surfactants and pore expanders. Specifically, large pore hydroxyapatite particles have been synthesized using 1-dodecanethiol (RSH) as a pore expander and CTAB as cationic surfactant [11]. Swelling of particles was reported to be a consequence of electrostatic interactions between the dissociated 
1-dodecanethiol molecule (RS $\left.{ }^{-}\right)$and the cationic molecules of the surfactant $\left(\mathrm{CTA}^{+}\right)$. A decrease in particle length/diameter ratio with the increase in the synthesis temperature and the RSH/CTAB ratio (R) was observed (Figure 1).

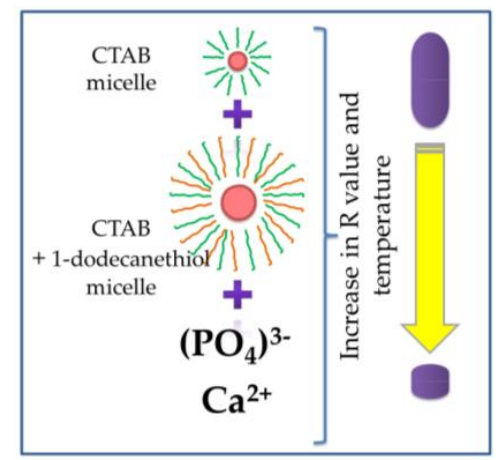

Figure 1. Scheme showing the morphological changes of hydroxyapatite (HAp) induced by the increase of temperature and the change of $\mathrm{R}$ ratios. CTAB for cetyltrimethylammonium bromide. Adapted from [11], Elsevier, 2016.

The common methods applied to produce HAp usually require relative long times (e.g., $24 \mathrm{~h}$ ) and need elevated processing conditions such as high $\mathrm{pH}$, temperature or ultra-sonication, which usually rendered HAp with properties deviating from biological apatite. Moreover, HAp is usually produced according to the stoichiometric $\mathrm{Ca} / \mathrm{P}$ ratio being absent other ions (e.g., $\mathrm{Na}^{+}, \mathrm{K}^{+}, \mathrm{Mg}^{2+}, \mathrm{Cl}^{-}$, $\mathrm{HCO}_{3}{ }^{-}$, and $\mathrm{SO}_{4}{ }^{2-}$ ) found in bones. An interesting approach to overcome these difficulties has been proposed [30] and specifically a simulated body fluid (SBF) with a similar salt composition to human blood plasma and an increased precursor concentration (i.e., $\mathrm{Ca}^{2+}$ and $\mathrm{PO}_{4}{ }^{3-}$ ions increased to 3.5 times) has been revealed effective. Preparation of this "bone like" carbonated HAp could be performed in only $3 \mathrm{~h}$, having formed nHAp crystals with a uniform rod shape of dimensions close to $27 \mathrm{~nm} \times 7 \mathrm{~nm}$. The short time required for preparation of nHAp makes this methodology highly promising for the development of HAp coatings on metallic biomaterials since productivity should be improved. In addition, short times would be helpful for using cells in combination with biomimetic nHAp in situ during coating processes.

A recent but alternative approach to prepare nanoparticles is based on the use of synthetic templates which act as molecular cages that are able to block reactions in the nanoscale region [31-33]. This process has been successfully applied for preparing HAp nanoparticles using cages of saccharides that are stabilized by strong intermolecular interactions (Figure 2) [34].

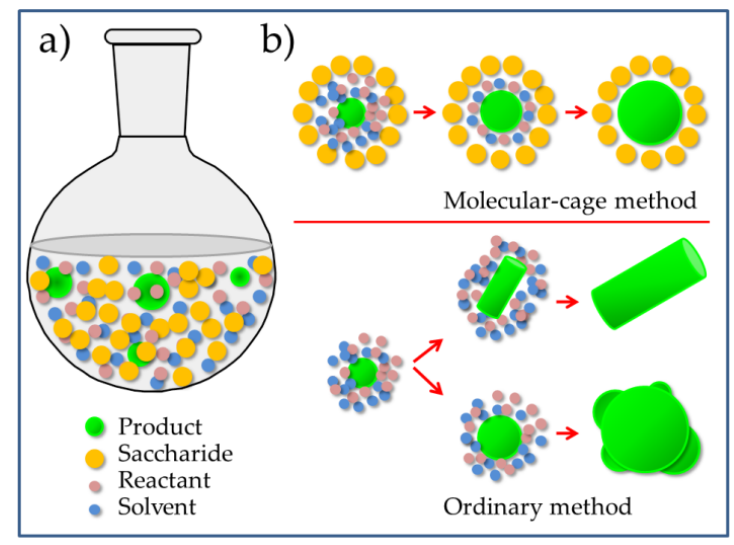

Figure 2. (a) Scheme showing the molecular cage system; (b) comparison between molecular-cage and ordinary method. Adapted from [34], American Chemical Society, 2016. 


\section{Preparation of Bionanocomposites Incorporating HAp}

Polymers incorporating nHAp particles can be considered inside the bionanocomposite group, which corresponds to a novel class of nanostructured hybrid materials. In general, this group involves multiphase materials that should contain at least one phase of biological origin and particles with at least one dimension on the nanometer scale. The resulting hybrid materials usually have improved functional and structural properties with respect to the constitutive phases. Development of bionanocomposites based on HAp opens multiple prospects, which mainly concern to the biomedical field and more specifically to the hard tissue engineering. In any case, the progress on such materials requires the research on multidisciplinary fields such as the production of bioinspired materials and biomimetic systems as well as the comprehension of biomineralization processes.

\subsection{Bionanocomposites}

Combination of HAp with another biopolymer can help to overcome certain inherent limitations such as poor load bearing properties, difficulty to be processed in a determined shape and high mobility [35,36]. Multicomponent materials are designed to provide the appropriate combination of properties for each specific application. However, typical phase separation problems, which can arise along time, should be avoided. Coating or grafting of HAp nanoparticles with polymers compatible with the polymer/copolymer matrix are good approaches. For example, polylactide (PLA) was easily grafted on the surface of nHAp particles through reaction with their surface hydroxyls and then incorporated in a poly(L-lactide-co-glycolide) (PLGA) matrix in such a way that improved properties, tensile strength and dispersability were observed with respect to ungrafted systems [37].

Chitosan [poly- $\beta(1 \rightarrow 4)$-2-amino-2-deoxy-d-glucose] (CHI) is obtained by deacetylation in strong alkaline solutions and by enzymatic hydrolysis of chitin (poly-( $1 \rightarrow 4)-\mathrm{N}$-acetyl-glucosamine), which is the second most abundant natural polymer. $\mathrm{CHI}$ is biocompatible, biodegradable and has interesting properties (e.g., antimicrobial and antioxidant activities) that justify its use in multiple fields such as biology, food nutrition, medicine (e.g., tissue engineering), and pharmacy [38-42]. CHI based tissues should mimic the behavior of the replaced tissue, being an ideal system with a practically insoluble outer surface and an inner surface (i.e., in contact with the tissue) capable to experience a progressive degradation and a complete resorption after finishing the regeneration process.

Carboxymethylated-chitosan (CMC) has some advantages with respect to chitosan due to its higher solubility (e.g., in water, alkaline solutions and physiological conditions). More interestingly, CMC is capable to adsorb calcium ions and has a great influence on precipitation of biominerals [43,44], even enhancing bone regeneration.

nHAp particles have been easily embedded in CHI and CMC matrices, following a one-step co-precipitation method in water [45]. Selected biopolymers act as capping ligands able to control both nucleation and growth rate of HAp during the precipitation process while serve to give rise to a biocomposite network. In this sense, CMC was able to produce lower size and narrower size distribution of HAp particles and higher cell viability of the bionanocomposite caused by the higher surface of particles.

The sol-gel method has been applied to produce new bionanocomposites based on HAp nanopowders doped with calcium fructoborate, which have promising applications as osteosynthesis materials [46].

Nanocomposites of cellulose and HAp can be used as synthetic grafts since may accomplish many of the strict requirements requested for bone graft substitutes (i.e., mechanical support and moderate stiffness, capability of integrating with the host bone tissue, biocompatibility, enhancement of bone regeneration and biomechanical stability) [47-50].

Bacterial cellulose (BC) is having currently an increasing attention for tissue engineering applications due to its good specific properties (high water holder capacity, purity, crystallinity, mechanical strength and ultrafine fibrillar structure) [51]. Nevertheless, its high production costs hinder its commercial use. In order to get cheaper nutrient sources, BC has been produced from 
agroindustrial waste, being also observed that HAp was deposited with relatively good uniformity between nanobiofibers giving rise to similar characteristics than biological apatite [51].

\subsection{Electrospun Scaffolds Incorporating HAp Nanoparticles}

Electrospinning is an easy and low cost technique able to produce micro/nanofibers through the application of a high electrical field [52]. A charged polymer jet is formed when the applied electrostatic charge overcomes the drop surface tension of a polymer solution slowly ejected through a capillary. The jet is subsequently collected on a grounded collector giving rise to porous scaffolds after their accumulation. Control of processing parameters (e.g., voltage, flow rate and tip-collector distance), solution properties (e.g., solvent, polymer concentration and viscosity) and environmental conditions (e.g., humidity and temperature) allows tailoring the morphology of the derived fibers [53]. Moreover, electrospinning allows easy incorporation of drugs and nanoparticles into the fibers by dissolving/dispersing them into the initial polymer solution. Electrospinning is therefore appropriate to get fibers with comparable dimensions to fibrils existing in the extracellular matrix (ECM), porous scaffolds suitable for cell colonization and materials with enhanced bioactivity. Cautions must be taken into account when toxic organic solvents are employed and, consequently, different emulsion processes have been considered [54-56].

Electrospinning of polymer solutions incorporating HAp nanoparticles may cause some problems like the decrease of mechanical properties and loss of structural stability of the final scaffold due to the lack of adhesion between the inorganic and the organic phases [57]. HAp nanoparticles are therefore usually grafted with an organic and biodegradable polymer to facilitate their adhesion with the polymer matrix. Different examples can be found as the successful electrospinning of poly(lactic-co-glycolic acid) and HAp grafted with polylactide (PLA) as compatibilizing agent [58]. A second option to improve interactions between the inorganic and the organic component is based on the coating of HAp nanoparticles with lipophilic compounds such as oleic acid [59].

Incorporation of HAp nanoparticles can influence the morphology and structure of electrospun scaffolds [60]. In general, fibers tend to be thicker and irregular with increasing HAp content. Nevertheless, a correct adjustment of electrospinning parameters may lead to homogeneous distributions of inorganic particles without formation of clumps inside or between the fibers.

The effect of scaffolds having HAp nanoparticles on the grown of human bone-derived cells has been extensively evaluated [61]. Interestingly, the increase on HAp content stimulated the proliferation of osteogenic cells due to different effects: (a) upregulated expression of genes associated to gene expression [62]; (b) mitogenic effect of HAp crystals [63]; and (c) reinforcement effect that improves mechanical properties and lead materials with better capacities to support cell colonization [64]. The improvement of osteoconductivity is clear for example for chitosan based scaffolds [65]. Furthermore, polymeric fibers containing HAp have been revealed as promising candidates for guided bone regeneration [65].

Electrospinning of demineralized bone matrices (DMBs) has also been assayed as a natural material that contains the protein components of bone (e.g., adhesion ligands and osteoinductive signals, such as growth factors). Diameter size and distribution of fibers was strongly depended on the viscosity of the solution (1,1,1,6,6,6-hexafluoroisopropanol/trifluoroacetic mixture), which increased with the solubilization time (Figure 3). The process can be performed without the use of a carrier polymer [66] and can take profit of a subsequent treatment with glutaraldehyde vapors to improve mechanical performance. The ultimate strain of the crosslinked sample was $8.85 \%$ and the Young's modulus obtained from the linear region of the stress-strain curve $3.37 \mathrm{MPa}$.

Embedding HAp particles inside electrospun nanofibers may render a low bioactivity and a decrease of mechanical properties [67]. Thus, mineralization of the scaffold surface is an alternative that may be problematic if non-porous structures are derived (e.g., samples obtained by long time SBF treatments). 
A process that combines electrospinning and electrodeposition techniques (Figure 4) has recently been proposed in order to get mineralized electrospun nanofibrous scaffolds for bone tissue engineering applications [68]. Final morphology of such scaffolds showed the development of flat-like HAp crystals that contrast with the core-shell structure developed by standard SBF mineralization processes (Figure 4) [68].

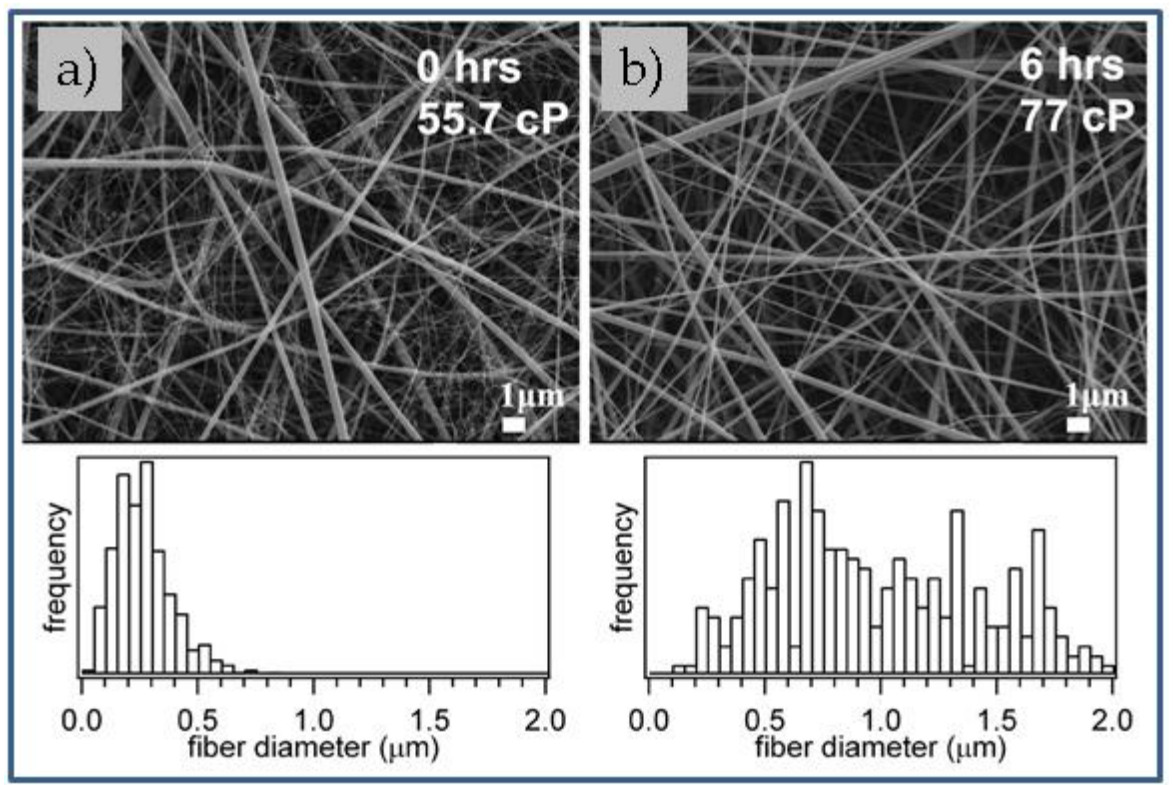

Figure 3. Representative SEM images and fiber diameter distributions of electrospun DMB fibers from a 7:3 mixture of 1,1,1,3,3,3-hexafluoroisopropanol/trifluoroacetic acid mixture processed immediately after dissolution (a) or after $6 \mathrm{~h}(\mathbf{b})$. Reproduced with permission from [66], American Chemical Society, 2014.

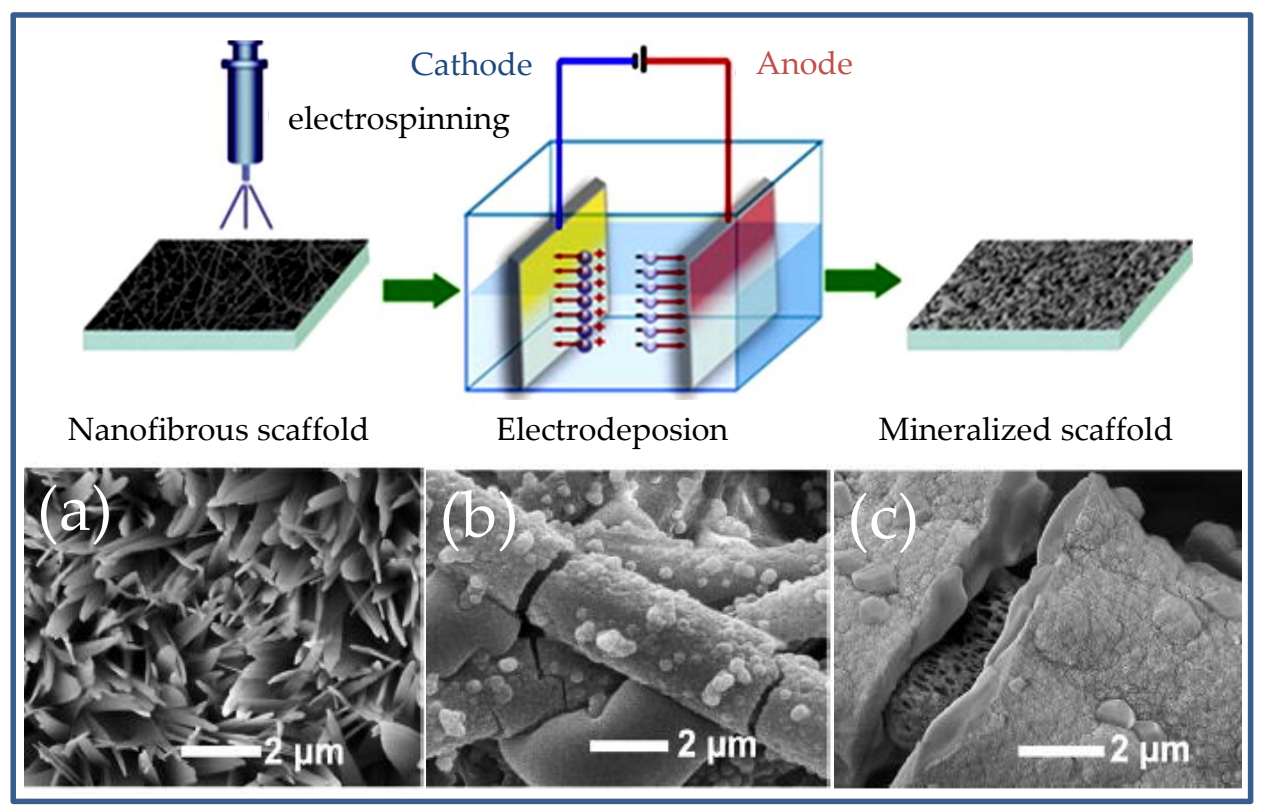

Figure 4. Scheme showing the fabrication of mineralized nanofibers by means of a final electrodeposition step (top). SEM micrographs of mineralized PLLA matrices are shown in the bottom: (a) electrodeposition at $3 \mathrm{~V}, 60^{\circ} \mathrm{C}$ for $60 \mathrm{~min}$; (b) mineralization in SBF for 12 days; and (c) mineralization in SBF for 30 days. Reproduced with permission from [68], Elsevier, 2013. 


\section{Functional HAp Biocomposites through Modification/Encapsulation Techniques}

\subsection{Antimicrobial Scaffolds Based on HAp}

Microorganisms can grow and survive for long periods of time into material surfaces developing biofilms through several common steps (e.g., reversible and irreversible attachments, maturation and dispersion $[69,70])$. The problem of biofilm formation is enhanced in hospital environments, being high the risk associated to the development of chronic infections and surgical site infections (SSI) [71,72]. In fact, approximately the 50\% of infections acquired in hospitals are associated to implants [73], a problem that is expected to increase as consequence of their continuously increasing consume. Therefore, it is important to produce HAp nanoparticles with antibacterial properties, independently of using a matrix that could also display such activity. Although incorporation of antibiotics was firstly considered, other preventive solutions are being developed because the increasing resistance of microorganisms towards antibiotics [74,75]. Today, one of the best and simplest methods to provide HAp with antibacterial properties consists on the incorporation of silver ions, which can inhibit the bacterial growth according to different mechanisms (e.g., disruption of cell membrane due to positive charges, deactivation of enzymes by binding to their thiol groups, inhibition of phosphate uptake, modification of DNA structure, and production of reactive oxygen compounds [76-79]).

Some caution should be taken into account when silver ions are incorporated into the scaffold since a cytotoxic effect could be derived as a consequence of a high load or even of a fast and local release. Ions can be incorporated by a simple and highly effective co-precipitation process (addition of a phosphate precursor over a mixture of calcium and silver precursors) and by ion exchange processes that should render a higher silver concentration on the HAp surface [80-82]. In any case, a compromise between the bactericide effect and the derived cytotoxicity should be taken into account, being reported as optimal a silver content of $0.5 \mathrm{wt} \%$ for samples prepared by co-precipitation. Properties and biological response depend on the preparation method and, logically, an immediate but not sustainable effect could be expected for samples obtained by ion-exchange. In this case, a greater toxicity due to a local high concentration of released ions could be expected.

Few works have been reported concerning systems that incorporate nHAp particles loaded with antibiotics. A bioresorbable composite of calcium sulfate and nHAp particles was studied considering its antibiotic release properties and biocompatibility. This composite showed excellent properties regarding resorption, biocompatibility and release of gentamicin and vancomycin as model studied antibiotics. The release of gentamicin and vancomycin was $94.7 \%$ and $96.3 \%$ after 10 days of exposure to phosphate-buffered saline (PBS) medium, respectively. The concentrations of released gentamicin and vancomycin exceed 100-fold and 10-fold the minimal inhibition concentrations (MICs) of susceptible Staphylococcus aureus within the first $24 \mathrm{~h}$ and for three and four days, respectively. Furthermore, it was probed that substitution of calcium sulfate by HAp decreased the inherent cytotoxicity of the sulfate [83].

Silver nanoparticles (AgNPs) possess excellent bactericide activity but applications are limited by their strong tendency to aggregate, which decreases their antimicrobial activity. This feature can be avoided by the fabrication of particles having AgNPs immobilized on their surface. One-dimensional nanowires appear an ideal morphology for supporting AgNPs due to unique properties such as ability to organize into three-dimensional networks that form porous macrostructures. In this way, free-standing inorganic films with bactericide activity have been prepared from ultralong hydroxyapatite nanowires (Figure 5) [84]. These nanocomposites were obtained from a one-step solvothermal process and utilized for the construction of inorganic paper through a simple vacuum-filtration procedure. The amount and particle size of silver nanoparticles clearly increased with higher concentrations of silver nitrate (i.e., particle sizes of 4.5, 12.5, 22.5 and $27.5 \mathrm{~nm}$ with silver content of $0.174,0.921,2.25$ and $5.19 \mathrm{wt} \%$ could be achieved, respectively). 


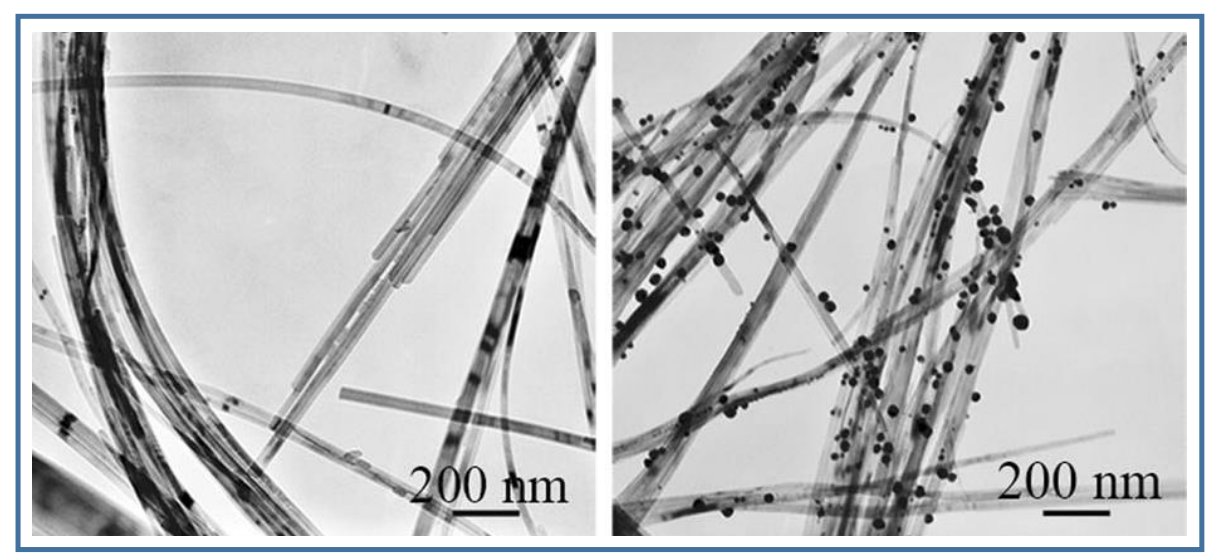

Figure 5. TEM micrographs of HAp nanowires with (right) and without (left) Ag nanoparticles prepared by one-step solvothermal method at $180{ }^{\circ} \mathrm{C}$. Reproduced with permission from [84], John Wiley \& Sons, Inc., 2016.

Copper and zinc substitution for Ca in HAp structures can be easily performed using solid state interaction, ion-exchange procedure or sorption process [85]. Relatively high amounts of incorporated ions can give rise to a clear bactericide effect; especially when copper is incorporated [85]. Thus, $\mathrm{Ca}_{10-x} \mathrm{Cu}_{x}\left(\mathrm{PO}_{4}\right)_{6}(\mathrm{OH})_{2}(x=0.05-2.0)$ was obtained by a co-precipitation method and the antibacterial ratio against $S$. aureus was found to reach a value of $98 \%$ when $x$ was only 0.2 [86]. The content of $\mathrm{Cu}^{2+}$ and $\mathrm{Zn}^{2+}$ in the solid samples logically depended on the concentration of the additives in the initial solutions, being the morphologies of particles approximately spherical with sizes in the range $10-20 \mathrm{~nm}$.

\subsection{Modification of HAp Nanoparticles and Doping with Fluorescent and Magnetic Ions for Imaging Applications}

Lanthanide ion doped nHAp particles have been considered as highly promising fluorescent bioprobes for cell imaging applications [87-89]. Control of size and morphology of nHAp is extremely important since inevitably influences the imaging quality. To this end, hydrothermal synthetic routes based on a liquid-solid-solution strategy have been employed [90]. Usually, hydroxyl groups of the HAp lattice are substituted by fluoride ions in order to avoid that the excited state of lanthanide ions was quenched by hydroxyls.

The resulting fluoride substituted HAp nanorods (FAp) have a hydrophobic surface, making difficult their dispersion in aqueous media and hindering biomedical applications [91,92]. Different surface modifications have been proposed to overcome this limitation and therefore commercially available amphiphilic polymers have been employed. These can establish hydrophobic interactions between the hydrophobic segments of polymers and the alkyl chain of coated HAp nanomaterials while keeping their polar groups in contact with the aqueous medium [93,94]. Diblock synthetic polymers derived from stearyl methacrylate (SMA) and poly(ethylene glycol) methacrylate (PEGMA) have been effectively employed as amphiphilic copolymers. FAp particles previously coated with oleic acid and doped with $\mathrm{Eu}^{3+}$ were able to interact with the diblock copolymer giving rise to stable particles in aqueous solution that kept fluorescent properties (Figure 6) [95].

Phosphor nanoparticles with a crystalline matrix doped with lanthanide ions (e.g., $\mathrm{Yb}^{3+}, \mathrm{Er}^{3+}$, and $\mathrm{Nd}^{3+}$ ) can act as upconversion fluorophores that are able to convert low energy photons, usually near-infrared region (NIR), to higher energy visible emissions. It should be pointed out that NIR imaging appears as an excellent strategy for visualizing morphological details in tissues because this technique causes a minimum damage while having an innate low auto-fluorescence. It is therefore an ideal imaging technique that makes it possible to attain a deep tissue penetration, high sensitivity and both high spatial and temporal resolution [96]. 


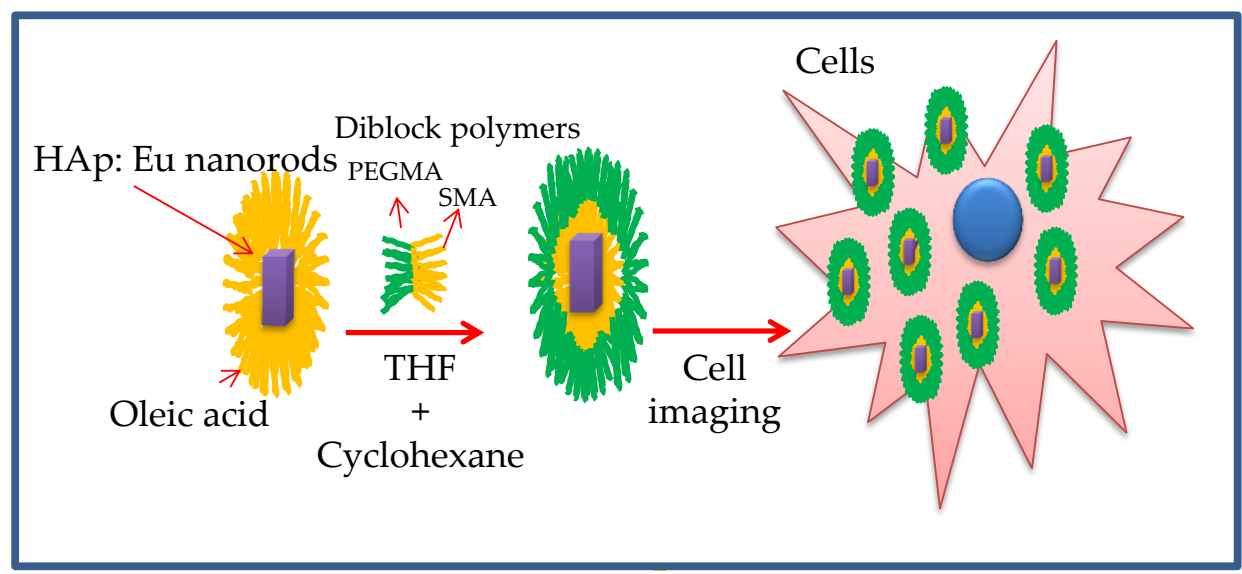

Figure 6. Surface modification of oleic acid coated fluoridated hydroxyapatite (FAp) with amphiphilic molecules via hydrophobic interactions and cell imaging application. Adapted from [95], Royal Society of Chemistry, 2013.

Potential biomedical applications (e.g., imaging, sensors and theranostic systems) of polymeric luminescent nanomaterials based on dyes with aggregation-induced emission (AIE) have been recently reviewed by Zang et al. [97]. AIE is a distinctive fluorescence phenomenon characterized by a strong emission when molecules aggregate instead of remaining in solution. The use of luminescent silica nanoparticles has been extensively studied taking profit from the aggregation of dye molecules in their core. Efficient encapsulation of AIE dyes in HAp nanoparticles has also been demonstrated. Thus, mesoporous HAp containing (4,4'-(1,2-diphenylethene-1,2-diyl) bis(4,1-phenylene))bis(methylene)diphosphonic acid was synthesized by a one-pot condensation process (tetraphenylethene (TPE) being the AIE-active center). Active molecules were incorporated in the three-dimensional network HAp structure through $\mathrm{P}-\mathrm{O}-\mathrm{Ca}$ covalent bonds and gave rise to strong fluorescence property and good biocompatibility [98]. Cell viabilities of extract solutions of these luminescent nanomaterials incubated with human hepatoma cells for $24 \mathrm{~h}$ were above $95 \%$ even when the concentration of the extract solution was about $40 \mathrm{mg} \cdot \mathrm{mL}^{-1}$.

Magnetic based nanoparticles have a great interest in medicine, for example in the detections of tumors via noninvasive magnetic resonance imaging [99]. Contrast agents are based on paramagnetic, super-paramagnetic and ferromagnetic materials able to change the image contrast between normal and diseased tissues [100]. The technique allows tomographic observation of structures with high resolution and soft tissue contrast. Nanosized contrast agents have great advantages derived to their high surface area and the capability to be delivered to a specific tumor by appropriate targeting and control over the blood circulation half-life [101,102].

Super-paramagnetic HAp has wide application in biomedicine that covers the enhancement of osteoblast functions [103], thermal treatment (hyperthermia) [104] and more recently for magnetically assisted drug delivery. In this case, super-paramagnetic iron oxide nanoparticles (SPIONs) were coated with mesoporous HAp. These nanocomposites were appropriated for loading anticancer drugs (e.g., doxorubicin, DO) (Figure 7) and for achieving targeted drug delivery through the hyperthermic effect provided by SPIONs [105]. 


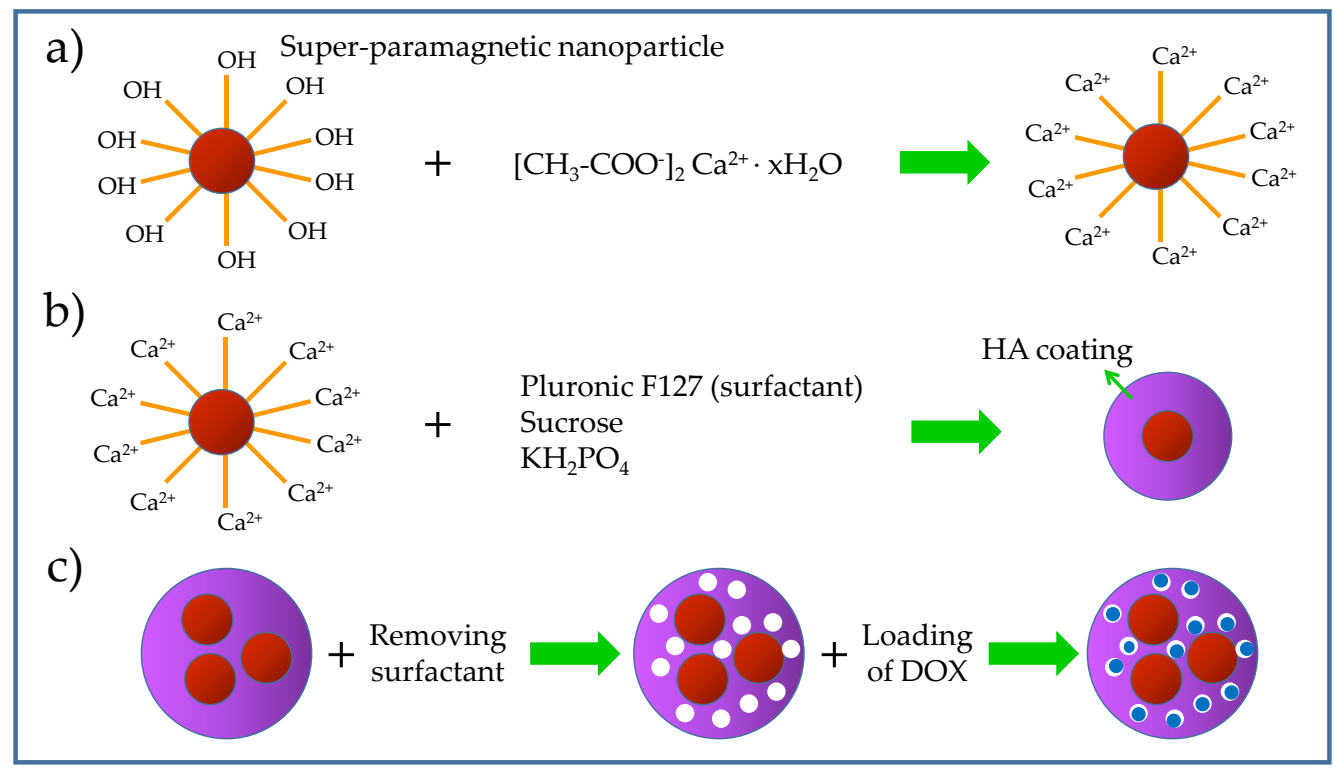

Figure 7. Scheme showing the synthesis of super paramagnetic mesoporous HAp nanoparticles as a carrier for DOX. (a) SPION conjugation for the formation of super paramagnetic Hap; (b) Formation of a mesoporous HAp with nanometer pores in combination with SPIONs as a core; (c) DOX molecules loaded into the magnetic nanoparticles coated with mesoporous HAp by a diffusion process. Adapted from [105], Elsevier, 2016.

\subsection{Hydroxyapatite as Non-Viral Gene Delivery System}

Non-viral vectors have some advantages with respect to viral systems despite showing usually lower transfection efficiency. Low cost, adaptability for large scale production, high reproducibility and potential non-immunogenicity are positive characteristics that make non-viral vectors a promising alternative [106]. CaP based systems are highly interesting due to the capacity of calcium ions to form ionic interactions with the phosphates of DNA, leading to complexes able to be transported across cell membranes through a ion-channel mediated endocytosis [91]. In addition, CaPs have excellent biocompatibility and bioresorbability. Main disadvantages are associated to lower levels of gene expression [107] due to endosomal escape and partial protection of DNA from nuclease degradation [108].

$\mathrm{CaP}$ co-precipitation is a routine procedure applied for in vitro DNA transfection [109]. Nevertheless, its application in vivo is hampered due to the difficulty to guarantee the delivery of DNA to any cell type [110] and also the lack of control of the final particle size that lead to a poor experimental reproducibility [111]. Co-precipitation of CaP and DNA in the aqueous core of reverse micellar droplets has been proposed as good alternative since monodispersed particles with a size close to $80 \mathrm{~nm}$ in diameter could be obtained (Figure 8) [111]. Note that particles with sizes lower than $100 \mathrm{~nm}$ have been reported as appropriated to be endocytosed by cells [112].

The indicated methodology is also able to encapsulate $85 \%$ of DNA, which obviously become protected from an external DNase environment [113]. Plasmid DNA (pDNA) was for example effectively encapsulated in $\mathrm{CaP}$ nanoparticles that were specifically targeted to liver cells after appropriate surface modification [110]. Although the entrapped pDNA was highly protected from enzymatic degradation, the transfection efficiency was around $80 \%$. This limited value was attributed to a partial disintegration of DNA molecules during the ultra-sonication performed as prerequisite for re-dispersion of particles in aqueous buffered medium. The use of soft preparative methods that avoided ultrasonication clearly improved in vitro transfection efficiency in HeLa cell lines [110].

Different improvements concerning encapsulation have been formulated: (a) surface adsorption or biopolymers such as $\mathrm{CHI}$ in order to prevent particle aggregation [114]; (b) substitution of 
calcium cations by magnesium and/or strontium ions; and (c) anionic substitution of phosphates and hydroxyl ions by carbonate and/or fluoride ions [115-117]. In fact, ionic substitution may be beneficial because can hinder aggregation, may increase loading efficiency as a consequence of a higher charge density, and may enhance dissolution of the endocytosed particles [106]. Silicon substitution of HAp has also been explored for non-viral gene delivery because great changes of properties (e.g., morphology, cell parameters, surface properties, crystallinity and kinetics of dissolution) have been reported [118-120].

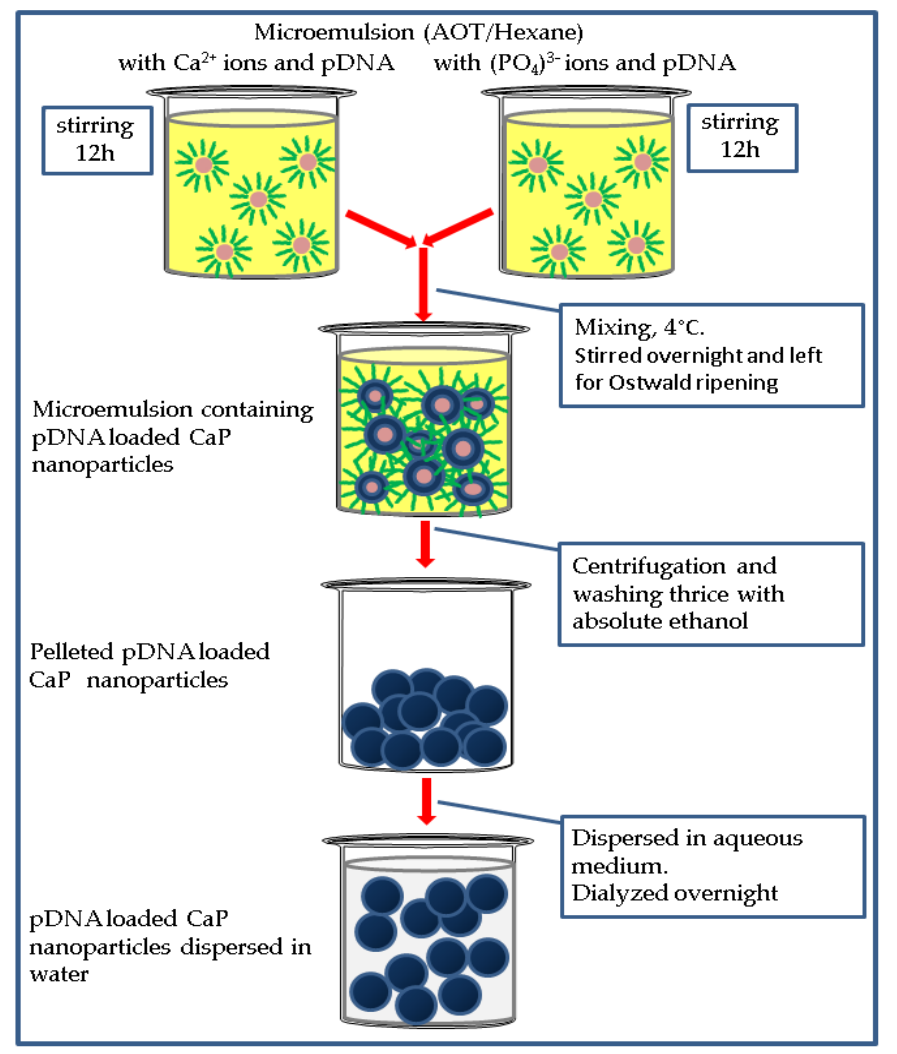

Figure 8. Flow chart showing the formation of nanoparticles encapsulating pDNA in the aqueous core of the bis (2-ethylhexyl) sulfosuccinate surfactant (AOT) microemulsion in hexane. The strategy involved the precipitation of the $\mathrm{CaP}$ in the aqueous core of the microemulsion droplets in the presence of pDNA. Adapted from [111], Elsevier, 2004.

Shekhar et al. [106] demonstrated that the structure of HAp could be retained up to a $18.6 \mathrm{~mol} \%$ of substitution of phosphates by silicates but an amorphous phase (i.e., for silicate contents between 16.6 and $33.3 \mathrm{~mol} \%$ ) and even new hydrated calcium silicate phases were formed at higher degrees of substitution. An additional $20 \%-50 \%$ increase in transfection was observed for particles containing $8.3-50 \mathrm{~mol} \%$ of silicate, owing to its rapid dissolution properties that makes feasible the escape of nanoparticles from lysosomal degradation. Silicate substitution higher than $60 \mathrm{~mol} \%$ resulted in considerable reduction in transfection.

Transfection efficiency of agents based on CaPs can be increased by protecting DNA with successive layers of $\mathrm{CaP}$ (Figure 9) through a multi-step precipitation process [121].

These multi-shell particles showed higher transfection efficiency than single cell particles since DNA became more protected against intracellular biochemical degradation. Moreover, these multilayered particles were capable to retain their activity during 2-3 months of storage. It was also demonstrated that the inclusion of a cationic peptide or polymer on such multi-shell nanoparticles could further enhance the transfection efficiency [122]. Specifically, a protamine sulfate-coated CaP 
showed higher efficiency to transfect human embryonic kidney cells after one week of storage at $4{ }^{\circ} \mathrm{C}$ than conventional CaP particles.

Cationic peptides rich on arginine are able to condense DNA improving transfection efficiency and protecting the polynucleotide from DNases. Tenkumo et al. [123] have proposed the use of scaffolds based on collagen and loaded with multi-shell nanoparticles incorporating a gene transfection agent (e.g., plasmid DNA) to allow invasion of cells that were subsequently transfected to first produce and then release growth factor proteins in a local area. In this way, typical problems of growth-factor releasing systems can be avoided: (a) a deficient tissue repair process due to a non-sustained release; and (b) a low local activity and concentration of growth factors at the last stages of the process.

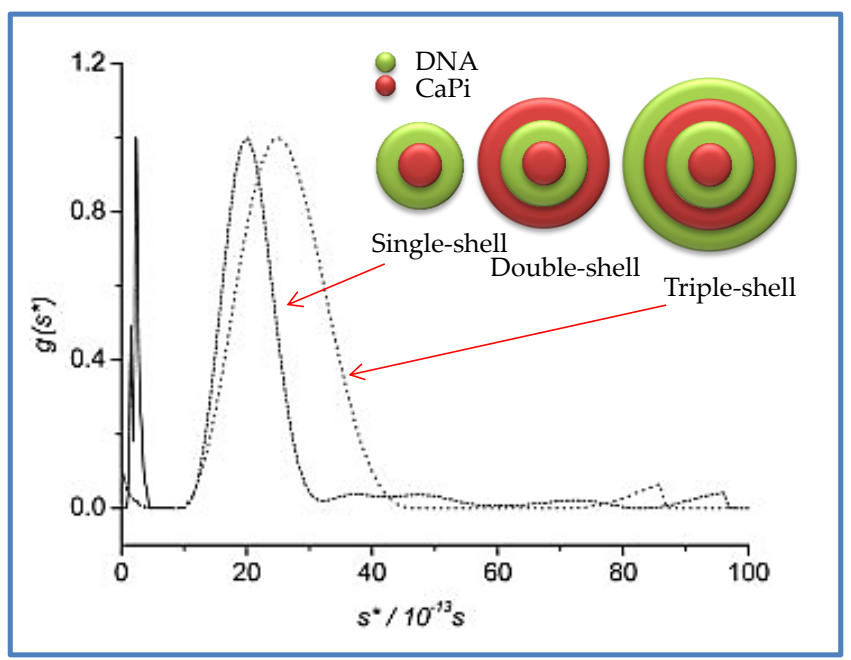

Figure 9. CaP/DNA nanoparticles with encapsulation of DNA by deposition of successive CaP layers, and their sedimentation coefficient distributions. Adapted from [121], John Wiley \& Sons, Inc., 2006.

Molecular dynamic simulations have been performed in order to demonstrate the ability of the $B$ double helix of DNA to be encapsulated inside HAp nanopores without causing a significant distortion in both the inter-strand hydrogen bonds and the intra-strand molecular stacking (Figure 10) [124].

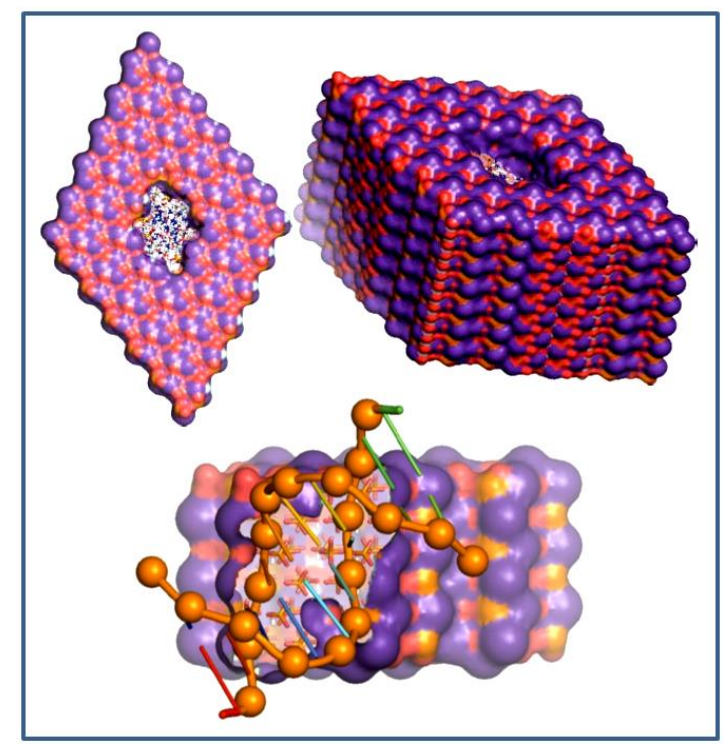

Figure 10. Simulated structure showing the double helix of B-DNA as a nucleating agent for the development of a HAp crystal. Reproduced with permission from [124,125], Springer-Creative Commons Attribution License, 2013; John Wiley \& Sons, Inc., 2014. 
The high stabilization between calcium ions of HAp and phosphate groups of DNA allowed the maintenance of the DNA secondary structure independently of its sequence. In contrast, similar calculations performed with fluoroapatite indicated the loss of DNA characteristics when the biomolecule was embedded in the mineral pores due to the lack of favorable electrostatic interactions. Molecular dynamic calculations showed that $\mathrm{CaP}$ clusters could be formed arising from DNA polyphosphate backbone. In fact, the strong electrostatic interactions (i.e., $\mathrm{Ca}^{2+}-\mathrm{PO}_{4}{ }^{3-}$ ) were essential to form ion complexes that served as nucleation sites of the indicated clusters. Moreover, temporal evolution of radial distribution functions derived from atomistic molecular dynamics simulations of aqueous solutions containing $\mathrm{Ca}^{2+}, \mathrm{PO}_{4}{ }^{3-}$ and $\mathrm{OH}^{-}$in the presence and absence of B-DNA demonstrated that DNA promoted mineral growth [126]. Effective encapsulation of DNA for both amorphous and crystalline HAp was unambiguously demonstrated by TEM, UV, XPS and gel electrophoresis (Figure 11) after removal of all superficially adsorbed DNA by digestion with deoxyribonuclease.

Theoretical calculations demonstrated that the exposed crystalline surface of HAp has a determinant influence on the adsorption capacity of DNA (Figure 12). Thus, the DNA secondary structure was well preserved on the (001) surface of HAp (Figure 12a) and even an attractive binding energy was determined. In contrast, repulsive interactions that led to DNA desorption were evaluated for the $\left(010 ; \mathrm{OH}^{-}\right)$surface. Finally, an attractive interaction that resulted in deformation of the double helix was observed for the (010; $\left.\mathrm{Ca}^{2+}\right)$ surface (Figure 12b) [127].

The acknowledge of the mechanism involved in the dissolution of HAp particles in acidic environments has been recently clarified [128,129] shedding light on the potential application of HAp as vehicle for gene delivery. Mechanism of dissolution in acid conditions of HAp nanoparticles encapsulating double-stranded DNA has recently been investigated at the atomistic level using computer simulations [130]. Results indicated a polynuclear decalcification mechanism with significant transfer processes, from the surface to the internal regions of the particle. Highly remarkable is the finding that biomineralization was highly effective to DNA protection, a feature with positive implications in biomedical fields.

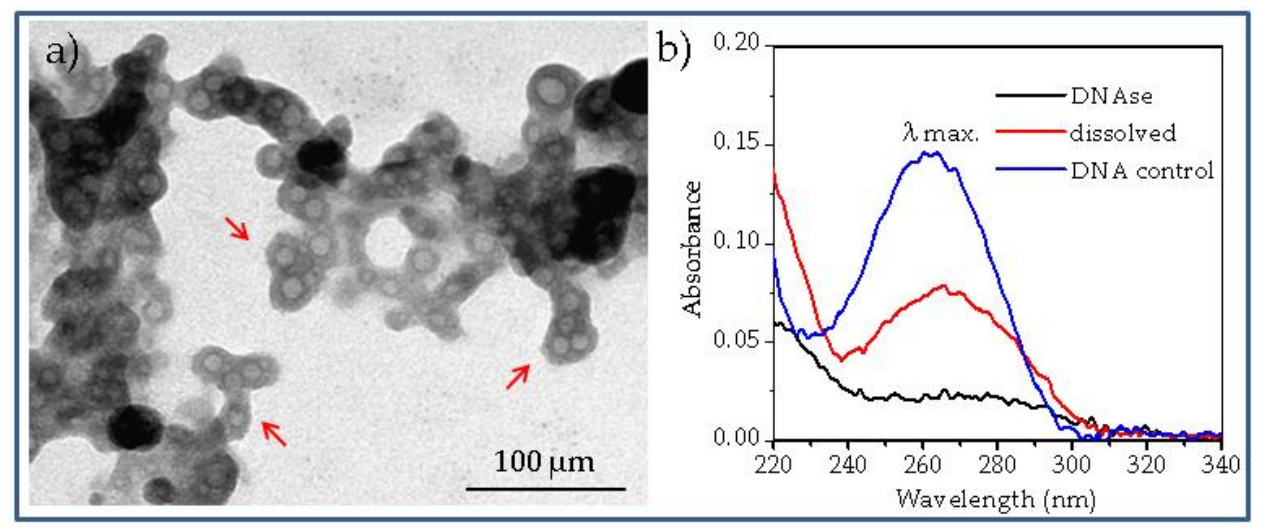

Figure 11. (a) TEM micrograph showing HAp-DNA nanocapsules. Red arrows point out capsules with a clearly distinctive contrast indicative of the encapsulated DNA in their inner part; (b) UV-vis absorption spectra of the aqueous solution/dispersion of HAp-DNA nanocrystals, sample digested with deoxyribonuclease to eliminate adsorbed DNA (black trace), corresponding samples after being dissolved in an acid medium (red trace), and DNA in aqueous solution (blue trace). Reproduced with permission from [126], Royal Society of Chemistry, 2013.

HAp protection of DNA may have had a very significant role on how DNA survived through mass extinction events, a concept that has recently been formulated and specifically the term of "hydroxyolites" has been introduced to appoint these particles with a protective function [131]. Uncontrolled DNA release from damaged cell nucleus together with calcium and phosphate ions 
that are also available in cells can initiate a biomineralization process that preserves DNA from further physical or chemical aggressions. Therefore, DNA was not degraded, denatured or modified, despite being an extremely fragile molecule. Genetic information could be transferred to next generations when there were conditions that are more favorable.

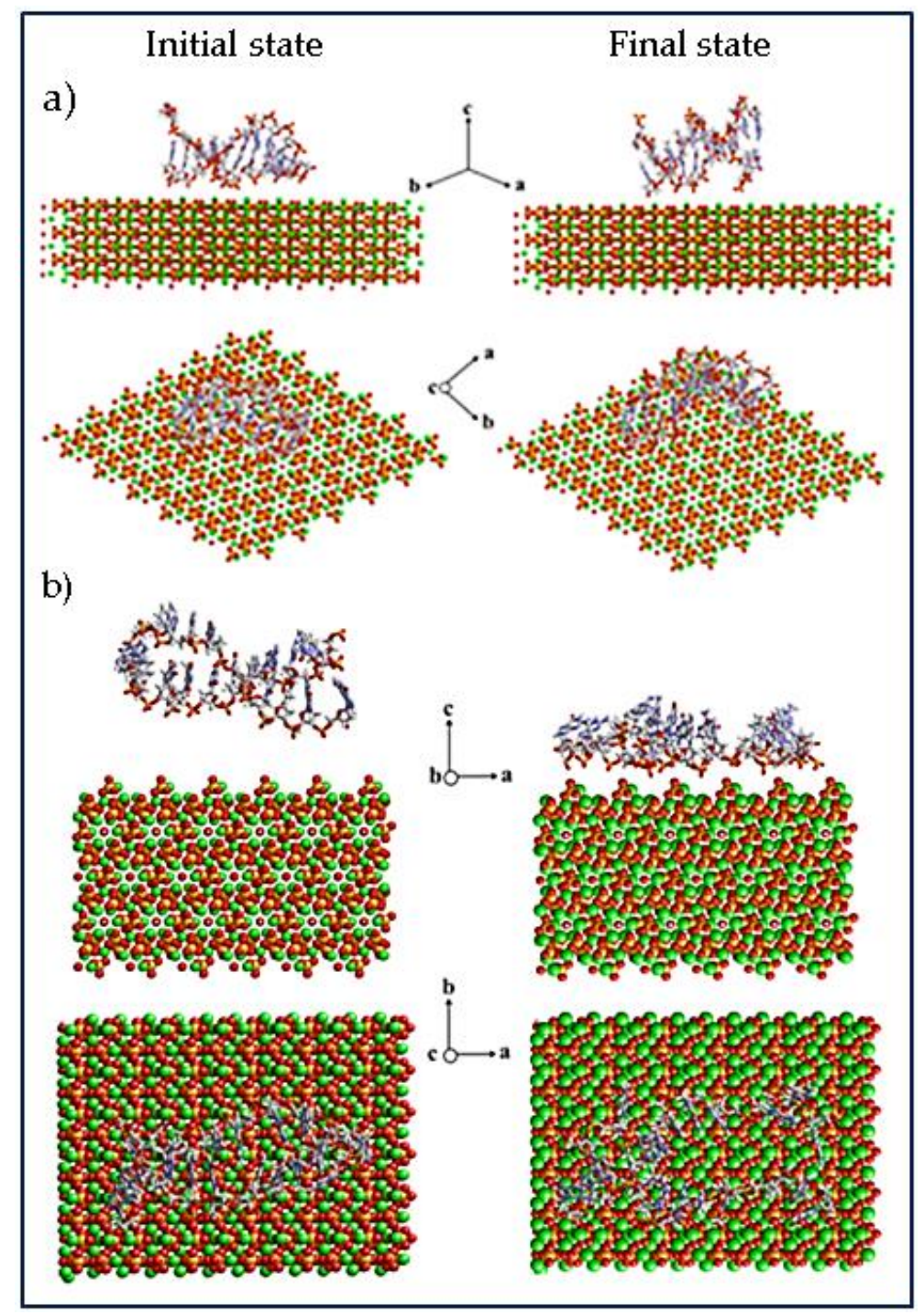

Figure 12. Snapshots showing the double helix of DNA adsorbed at the (001) (a) and (010; $\left.\mathrm{Ca}^{2+}\right)(\mathbf{b})$ surfaces of the HAp hexagonal unit cell with $P 6_{3} / m$ geometry $(a=b=0.9421 \mathrm{~nm}, c=0.6881 \mathrm{~nm})$ at the beginning (left) and the end (right) of the $15 \mathrm{~ns}$ isothermal-isobaric ensemble (NPT) molecular dynamic simulations. Reproduced with permission from [127], Royal Society of Chemistry, 2014.

HAp nanostructures have also been prepared using phages as template $[132,133]$. Phages were reported to be able to develop novel nanostructures and biomaterials but also to provide advantages in biomedicine that include molecular targeting, gene delivery and tissue regeneration [134]. Filamentous bacteriophages are genetically modifiable supramacromolecules constituted by a protein shell that is encoded by the DNA located in the core. Phages have a morphology that can mimic collagen fibrils and therefore they can be employed to arrange HAp nanocrystals into the extracellular matrix (ECM). For example, positively charged calcium ions could promote the self-assembly of negatively charged phages [132] or alternatively phages displaying a cationic peptide on their surface can be linked to phosphate ions [135]. 


\subsection{Protein Adsorption and Release from HAp Nanoparticles}

Adsorption of peptides and proteins onto HAp surfaces may favor cell attachment and cell differentiation events and consequently may play a fundamental role in bone remodeling. Great efforts have been focused onto the adsorption of growth factors (e.g., the arginine-glycine-aspartic acid peptide, RGD) and collagen proteins. This adsorption process does not depend on peptide/protein characteristics, such as conformation and functional groups, and HAp surface characteristics, such as roughness, porosity, pore size, charge and growth face. Ionic interactions are easily established through calcium and phosphate ions of HAp and the charged groups of the organic molecules $\left(\mathrm{NH}_{3}{ }^{+}, \mathrm{COO}^{-}\right)$.

Lysozyme (LSM) is a small globular protein containing 129 amino acid residues that is stabilized by four internal disulfide bridges and has a net charge that varies with $\mathrm{pH}$ [136]. LSM has a wide interest in biomedicine since it catalyzes the hydrolysis of the $\beta-(1,4)$ glycosidic bond of peptidoglycans that constitute the cytoplasmic membrane of Gram-positive bacteria [137]. Therefore, multiple applications can be derived from the design of LSM delivery systems [138]. The adsorption of LSM onto HAp surfaces has been proposed in order to avoid problems caused by the relative instability of the protein. Adsorption could be favored trough the strong interactions that could be established between phosphate groups and LSM functional groups. The adsorbed protein can moreover be easily delivered by competition with other cations of the buffer release medium [139]. Selenium substituted HAps have been revealed appropriate to increase the LSM upload (e.g., $41.7 \%$ versus the $34.1 \%$ determined for non-substituted HAp) and slow the protein release. The results are also interesting since selenium substituted HAp nanoparticles can induce both apoptosis of bone tumor cells and enhance osteointegration [140].

Nano-sized HAp particles with needle-like morphology were prepared by using carboxymethyl cellulose as the template. These particles derived from spherical amorphous CaP particles after aging (14 days) under ambient conditions. A high LSM adsorption capacity (i.e., up to $930 \mathrm{mg} / \mathrm{g}$ ) was observed as well as a pH-sensitive release of adsorbed LSM [141].

Surface charge of HAp nanoparticles can be modified by immobilization of amino acids by means of a precipitation process. Acidic amino acids (e.g., aspartic or glutamic acids) lead to a negatively charged surface that is ideal for the selective uptake of positive charged LSM. By contrast, basic amino acids (e.g., arginine) enhance the adsorption of negative charged proteins such as bovine serum albumin [142]. In the same way, organic compounds like mercaptosuccinic acid and citric acid were employed to increase the uptake of cytochrome C [143] and LSM [144], respectively. In the same way, the load of bone morphogenetic proteis could be enhanced (i.e., more than $50 \%$ increase in BMP-2 adsorption was observed when HA was prepared in the presence of $0.1 \mathrm{M}$ of $\mathrm{CA}$ ) and its release increased [144]. By contrast, zwitterionic amino acids, which contain two counter-charged groups and maintain overall charge neutrality, can prevent HAp surface from nonspecific protein adsorption and even provide clear antifouling properties [145].

Growth of HAp crystals is often inhibited by the adsorption of organic compounds (e.g., proteins and amino acids). This feature is highly interesting since a decrease on the degree of crystallinity should affect the mineralization of HAp and even could make feasible the attainment of a controlled solubility as recently proposed [146] when amino acids such as glycine, serine, aspartic acid and glutamic acid were considered.

Alpha(2)-HS glycoprotein/fetuin A (Ahsg) is a well-known inhibitor of precipitation of CaPs that prevents calcification processes. The effect given by fetuin $\mathrm{A}$ is a consequence of the formation of colloidal spheres capable of incorporating CaPs. New particles may also play a fundamental role concerning the transport of insoluble CaPs in the bodies of mammals and the subsequent delivery through solubilization of the Ahsg particles [147].

\subsection{Hydroxyapatite Nanoparticles As Carriers for Drug Delivery Systems}

HAp has extensive applications as a carrier for delivery systems of a large variety of therapeutic agents (e.g., drugs, genes, antigens, enzymes, proteins) [148,149]. HAp allows a control of textural 
parameters, pore size, surface area and surface functionalization, which have a primordial role in the design of drug delivery systems, as recently reviewed by Vallet-Regui et al. [150]. Different examples of recently published works can be explicitly indicated.

HAp coated liposomes have been demonstrated as an effective local drug delivery system for hydrophobic compounds like indomethacin, a nonsteroidal anti-inflammatory drug [151]. The coating of HAp decreased the release rate and specifically $20 \mathrm{~h}$ were necessary to deliver the $70 \%$ of the drug while only $5 \mathrm{~h}$ were required for the uncoated liposome [151].

Alendronate (Alen) is a bisphosphonate with a recognized therapeutic effect against osteoporosis due to its ability to suppress bone resorption by inhibiting osteoclast activity [152]. Combination of the osteocoductive properties of HAp and the therapeutic effect of Alen was achieved by conjugating it into the outmost layer of a layer-by-layer (LbL) HAp coating based on poly(allylamine) and alginate (ALG) (Figure 13).

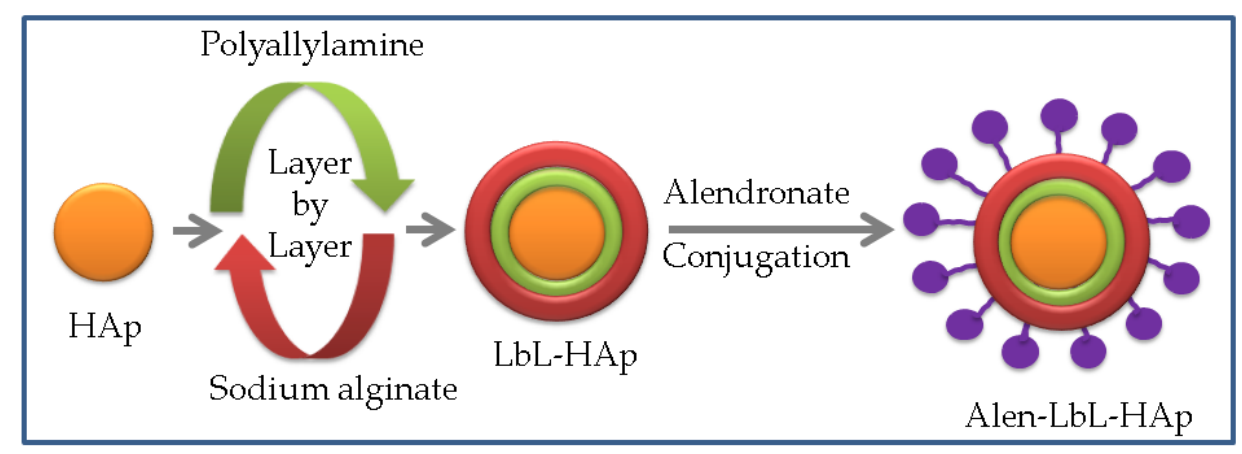

Figure 13. Scheme sowing the preparation of nHAp particles coated with a multilayer able to conjugate Alen. Adapted from [153], The Polymer Society of Korea and Springer Sciene + Business Media Dordrecht, 2016.

nHAp particles have also been considered for achieving $\mathrm{pH}$-responsive drug delivery taking advantage of the dissolution of HAp in acidic conditions [154]. For example, rhodamine 6G, a positively charged dye, was encapsulated in HAp nanoparticles coated with ALG (a biopolymer that provides excellent biocompatibility and surface functionality through their $\mathrm{COOH}$ groups) with a loading efficiency close to $63.0 \%$. The release at $\mathrm{pH} 2.0$ was found to be 2.5 times higher than the amount delivered after a similar period of $8 \mathrm{~h}$ [154].

Recent works have indicated that high concentration of HAp nanoparticles may show an antiproliferative and proapoptotic activity on cancer cells [155,156]. Specifically, adverse effects on the metabolic viability of several types of cancer cells (e.g., hepatoma, colon cancer, osteosarcoma, and melanoma) have been detected $[157,158]$. Apoptotic rate of human hepatoma BEL-7402 cells was $18.68 \%, 22.27 \%, 33.49 \%, 49.03 \%$, and $57.16 \%$ at 50, 75, 100, 150 and $200 \mathrm{mg} / \mathrm{L}$ concentration of HAp nanoparticles, respectively.

It was postulated that the main mechanism of growth inhibition by HAp nanoparticles in cancer cells was a consequence of the high calcium concentration and nuclear localization of the particles. Calcium ions can stimulate intracellular apoptotic signals (i.e., activation of protein digesting enzymes named caspases), which allow replacing old, damaged or dysfunctional cells. The anticancer activity of HAp has been specifically related to caspase activation and cytochrome $\mathrm{C}$ release from the mitochondria [159]. In fact, majority of anticancer drugs are designed to induce apoptosis through a mitochondrion-mediated pathway [160]. This favors the release of apoptogenic factors such as cytochrome $\mathrm{C}$ as well as the activation of caspases. The size of nanoparticles usually has a significant effect on the apoptotic efficacy, although this effect is not well established in the case of HAp nanoparticles.

Yuan et al. [159] evaluated the influence of the size of HAp nanoparticles in human hepatoma HepG2 model cells, being detected that apoptosis induction efficacy decreased in the order of $45 \mathrm{~nm}>26 \mathrm{~nm}>78 \mathrm{~nm}>175 \mathrm{~nm}$. Furthermore, particles with sizes between 20 and $80 \mathrm{~nm}$ were able to 
activate caspases and the release of cytochrome $C$ from mitochondria. The best efficiency was observed for $45 \mathrm{~nm}$-sized particles. Cellular response was therefore correlated with the cellular internalization of particles. More recently, the particle size and the specific surface area of different types of HAp nanoparticles were correlated with cytotoxicity to human gastric cancer cells, being clearly determined a higher toxicity when the smallest particles were employed [161]. Significant differences were found between rod shaped crystals with an average size of about $50 \mathrm{~nm}$ in length and $15 \mathrm{~nm}$ in width and needle-like crystals with dimensions close to $150 \mathrm{~nm}$ in length and $20 \mathrm{~nm}$ in diameter.

Enhanced permeability and retention (EPR) is a characteristic phenomenon of cancer tissues that promotes angiogenesis, hypervascularization, defective vascular architecture and increased production of permeability mediators $[162,163]$. Some cancer treatments takes advantage of EPR for selective targeting of cancer tumors by nanoparticles, being HAp highly promising due to its good biological characteristics and the potential control over morphology and size. It is also interesting the surface modification of nanoparticles and specially the coating of HAp with positively charged polymers such as $\mathrm{CHI}$ since electrostatic interactions will lead to an increased uptake efficiency by negatively charged cancer cell membranes $[164,165]$. This approach has been considered for treatment of colon cancer, which is the second leading cause of cancer-related deaths. Specifically, celecoxib was encapsulated in the HAp coated system due to its high efficiency in patients with precancer disease of the colon. Results proved that loaded nanoparticles were more potent in inhibiting tumor growth than free celecoxib, acting as a safe vehicle for targeted delivery that did not cause any serious side effect [162]. Human colon cancer cell untreated (control), or treated with free celecoxib, HAp-CHI or celecoxib-loaded HAp-CHI nanoparticles had $0.71 \% \pm 0.34 \%, 39.14 \% \pm 0.47 \%, 6.21 \% \pm 0.75 \%$ and $62.33 \% \pm 5.22 \%$ of apoptosis, respectively.

Smart theranostic nanoplatforms (i.e., integration of therapeutic payloads and diagnosis agents) based on neodymium doped HAp have been proposed for colon cancer detection and targeted therapy [166]. The incorporation of neodymium endowed near-infrared fluorescence ability to HAp particles for diagnosis as above explained. In addition, drug loaded HAp nanoparticles were coated with ALG (Figure 14) to get a $\mathrm{pH}$ responsiveness that was ideal for targeted drug delivery after oral administration. Size, morphology and negative zeta potential of nanoparticles were appropriate to favor cell internalization.

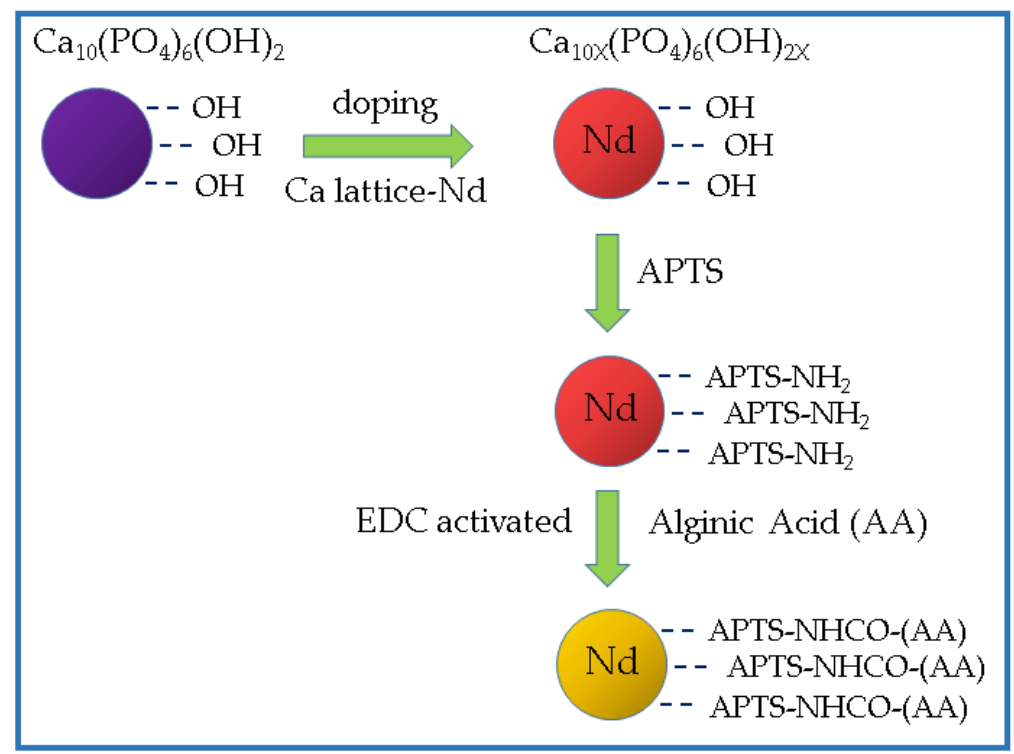

Figure 14. Scheme sowing the doping with $\mathrm{Nd}^{3+}$ cations of nHAp particles previously loaded with 4-amino salicylic acid as a model drug. Nanoparticles were subsequently coated with ALG via aminopropyltriethoxysilane (APTS) and 1-ethyl-3-(-3-dimethylaminopropyl) carbodiimide hydrochloride (EDC) mediated synthesis. Adapted from [166], Elsevier, 2016. 
The hydrophilic hyaluronic acid (HA) is a promising candidate polymer for targeting the CD44 glycoprotein that is overexpressed in tumor cells [167]. Therefore, attempts to coat nHAp particles with HA have been undertaken. Results indicated that a 9.4 times increment of the nanoparticle internalization by tumor cells was obtained [168]. In addition, the surface properties provided by HA (i.e., hydrophilicity and negative charge) could assist nanoparticles in evading the uptake by immune cells. In summary, HA was expected to facilitate tumor targeting delivery of nHAp particles, thereby it could enhance the in vivo efficacy of typical anticancer drugs as DOX (Figure 15).

Cancer can be treated by means of cytotoxic ROS and free radicals (i.e., photodynamic therapy) produced by exposing a photosensitizer to a specific light wavelength [169]. The technique is limited due to the low tissue penetration depth of visible light $(620-690 \mathrm{~nm})$ [170]. Therefore, new agents based on high atomic metallic ions are gaining interest because their ability to interact with ionizing radiation and generate free radicals for deeper cancer treatment. Metallic nanoparticles of high electron density (e.g., gadolinium-based, titanium-based, silver-based, and gold nanoparticles) are considered appropriate as ROS-enhanced radiosensitizers [171]. The direct use of such particles has inherent problems derived from the interaction of their reactive surface with healthy tissues and subsequent damage [172]. Chen et al. [173] have recently reported that HAp nanoparticules could be effectively doped with Hf ions giving rise to significant ROS formation in cells after irradiation with $\gamma$ rays, cell apoptosis and in vivo growth inhibition of lung cancer tumors. Preliminary in vivo results showed specifically that tumors grew promptly after seven days of treatment except for being treated by $\mathrm{Hf}$ (15 mol \%):HAp, of which approximately 30\% was inhibited relative to the starting tumor volume, and exhibited a relative delay of tumor growth until Day 14.

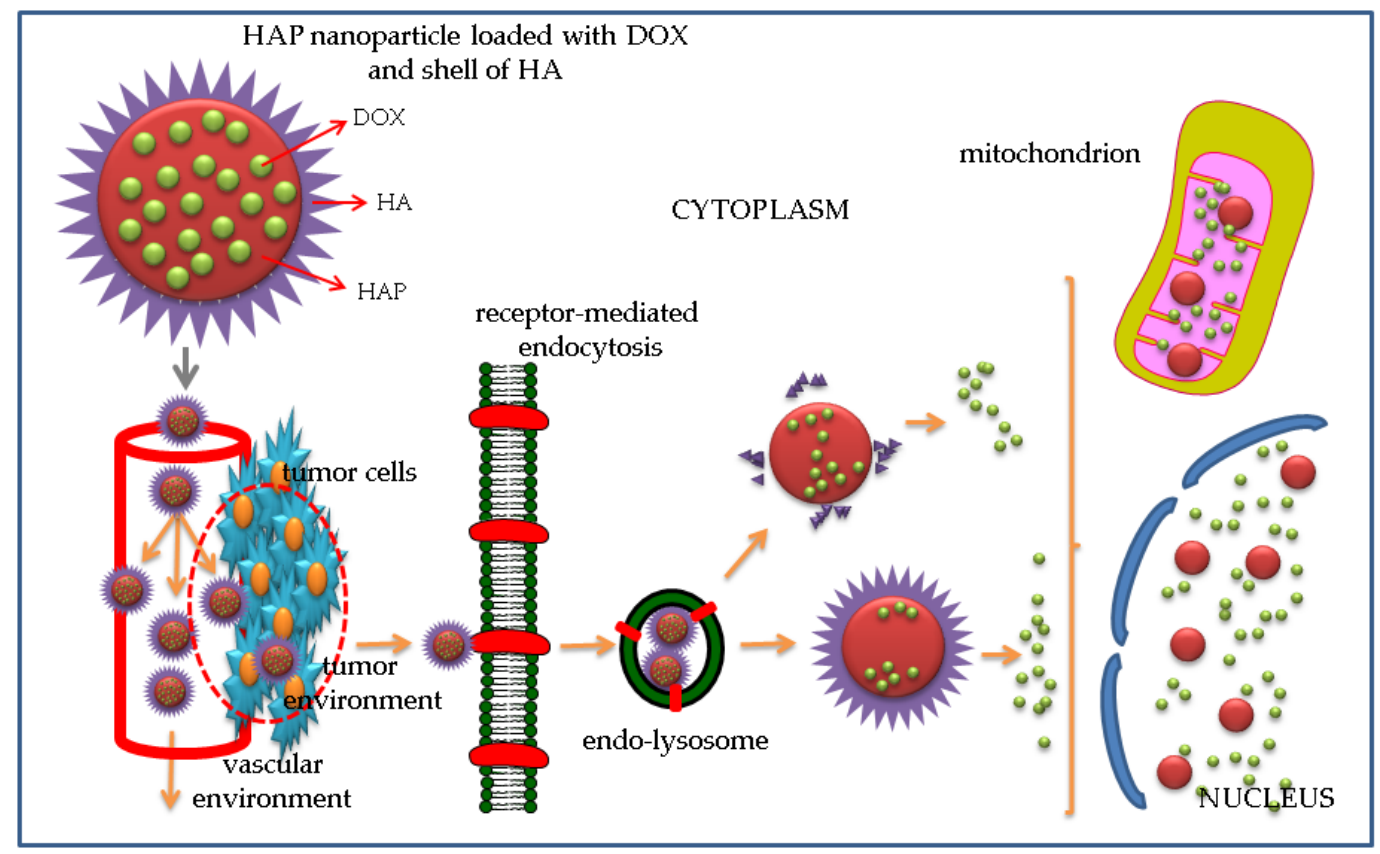

Figure 15. Scheme showing the targeted antitumor mechanism of HAP-HA nanoparticles loaded with DOX. Mechanism of drug delivery into the cell nuclei and mitochondria. Adapted from [168], Elsevier, 2016.

\section{Conclusions}

The use of HAp nanoparticles for the development of new biodegradable and biocompatible systems is a rich and active field of research. HAp adsorption and encapsulation capabilities of ions, molecules and biopolymers are of outmost interest as HAp is a highly biocompatible substrate. On the other hand, HAp by itself can be part of biodegradable and biocompatible systems acting as a secondary agent that contributes decisively to provide some added value properties to the main 
system. Furthermore, the possibility to act as a "Trojan Horse" when delivering drugs or genes to cells completes the extraordinary features of HAp.

This review has summarized representative research branches where HAp plays a relevant role. First, biocomposites developed in combination with chitosan derivatives, are reported to enhance bone regeneration where HAp contributes improving the mechanical properties. Second, technologies such electrospinning demonstrate the huge range of biocompatible systems affordable by adjusting the working parameters. Moreover, electrospinning technique allows controlling the performance of the polymeric fibers that contain HAp that even can include bioactive substances. Third, considering the relevance of the fight against biofilm formation on the surface of implanted medical devices, any antimicrobial strategy that can bring long term protection from biofilm formation is attractive and should be explored. Therefore, HAp is a polyvalent substrate that can incorporate both ions and molecules with antimicrobial activity that can be applied as a coating of such implants. Fourth, it cannot be overestimated the impact of imaging technologies in the medical diagnostic field. We can only expect an exponential development of such techniques. Biocompatible nanosubstrates, such HAp, in combination with biomarkers are good candidates for exploring the root cause and the development of diseases. Fifth, even though gene therapy is still under development, non-viral transfecting agents based on HAp are receiving more attention due to the lack of secondary effects. Intense research to increase the transfection efficiency is still fruitful but results are not completely satisfactory. The study of molecular mechanisms related to dissolution and transfection using HAp will decisively contribute to gene therapy development. Finally, controlled drug delivery systems are expected to open new therapies by means of delivering drugs after crossing biological barriers and attacking the core of the disease. The capability of HAp of masking biomolecules converts it into an excellent "Trojan Horse" that can deliver the drug just onto the target.

HAp attracts researchers from several fields, for that reason, a common platform of knowledge is necessary to be developed. This review contributes to such multidisciplinary approach to enlightening the HAp performance in the field of biodegradable and biocompatible systems.

Acknowledgments: The authors acknowledge support from MINECO and FEDER (MAT2015-69547-R and MAT2015-69367-R), and the Generalitat de Catalunya (2014SGR188).

Author Contributions: Pau Turon, Luís J. del Valle, Carlos Alemán, and Jordi Puiggalí equally contributed to the development of the review.

Conflicts of Interest: The authors declare no conflict of interest.

\section{References}

1. Wahl, D.A.; Czernuszka, J.T. Collagen-hydroxyapatite composites for hard tissue repair. Eur. Cell. Mater. 2006, 11, 43-56. [CrossRef] [PubMed]

2. Dorozhkin, S.V. Calcium orthophosphate bioceramics. Ceram. Int. 2015, 41, 13913-13966. [CrossRef]

3. Habraken, W.; Habibovic, P.; Epple, M.; Bohner, M. Calcium phosphates in biomedical applications: Materials for the future? Mater. Today 2016, 19, 69-87. [CrossRef]

4. Dorozhkin, S. Calcium orthophosphate-containing bionanocomposites and hybrid materials for biomedical applications. J. Funct. Biomater. 2015, 6, 708-832. [CrossRef] [PubMed]

5. Ma, P.X. Scaffolds for tissue fabrication. Mater. Today 2004, 7, 30-40. [CrossRef]

6. Uskokovic, V.V.; Uskokovic, D.P. Nanosized hydroxyapatite and other calcium phosphates: Chemistry of formation and application as drug and gene delivery agents. J. Biomed. Mater. Res. B Appl. Biomater. 2011, 96, 152-191. [CrossRef] [PubMed]

7. Verron, E.; Khairoun, I.; Guicheux, J.; Bouler, J.M. Calcium phosphate biomaterials as bone drug delivery systems: A review. Drug Discov. Today 2010, 15, 547-552. [CrossRef] [PubMed]

8. Dorozhkin, S.V. Multiphasic calcium orthophosphate $\left(\mathrm{CaPO}_{4}\right)$ bioceramics and their biomedical applications. Ceram. Int. 2016, 42, 6529-6554. [CrossRef]

9. Kay, M.I.; Young, R.A.; Posner, A.S. Crystal structure of hydroxyapatite. Nature 1964, 204, 1050-1052. [CrossRef] [PubMed] 
10. Layrolle, P.; Lebugle, A. Characterization and reactivity of nanosized calcium phosphates prepared in anhydrous ethanol. Chem. Mater. 1994, 6, 1996-2004. [CrossRef]

11. Bakhtiari, L.; Javadpour, J.; Rezaie, H.R.; Erfan, M.; Mazinani, B.; Aminian, A. Pore size control in the synthesis of hydroxyapatite nanoparticles: The effect of pore expander content and the synthesis temperature. Ceram. Int. 2016, 42, 11259-11264. [CrossRef]

12. Saha, S.K.; Banerjee, A.; Banerjee, S.; Bose, S. Synthesis of nanocrystalline hydroxyapatite using surfactant template systems: Role of templates in controlling morphology. Mater. Sci. Eng. C 2009, 29, 2294-2301. [CrossRef]

13. Xia, Z.; Liao, L.; Zhao, S. Synthesis of mesoporous hydroxyapatite using a modified hard-templating route. Mater. Res. Bull. 2009, 44, 1626-1629. [CrossRef]

14. Ye, F.; Guo, H.; Zhang, H.; He, X. Polymeric micelle-templated synthesis of hydroxyapatite hollow nanoparticles for a drug delivery system. Acta Biomater. 2010, 6, 2212-2218. [CrossRef] [PubMed]

15. Huang, Y.T.; Imura, M.; Nemoto, Y.; Cheng, C.H.; Yamauchi, Y. Block-copolymer-assisted synthesis of hydroxyapatite nanoparticles with high surface area and uniform size. Sci. Technol. Adv. Mater. 2011, 12, 045005. [CrossRef] [PubMed]

16. Sun, R.; Chen, K.; Lu, Y. Fabrication and dissolution behavior of hollow hydroxyapatite microspheres intended for controlled drug release. Mater. Res. Bull. 2009, 44, 1939-1942. [CrossRef]

17. Shum, H.C.; Bandyopadhyay, A.; Bose, S.; Weitz, D.A. Double emulsion droplets as microreactors for synthesis of mesoporous hydroxyapatite. Chem. Mater. 2009, 21, 5548-5555. [CrossRef]

18. Ma, M.G.; Zhu, J.F. Solvothermal synthesis and characterization of hierarchically nanostructured hydroxyapatite hollow spheres. Eur. J. Inorg. Chem. 2009, 36, 5522-5526. [CrossRef]

19. Dou, Y.; Cai, S.; Ye, X.; Xu, G.; Hu, H.; Ye, X. Preparation of mesoporous hydroxyapatite films used as biomaterials via sol-gel technology. J. Sol-Gel Sci. Technol. 2012, 61, 126-132. [CrossRef]

20. Wang, H.; Zhai, L.; Li, Y.; Shi, T. Preparation of irregular mesoporous hydroxyapatite. Mater. Res. Bull. 2008, 43, 1607-1614. [CrossRef]

21. Ng, S.X.; Guo, J.; Ma, J.; Loo, S.C.J. Synthesis of high surface area mesostructured calcium phosphate particles. Acta Biomater. 2010, 6, 3772-3781. [CrossRef] [PubMed]

22. Guo, Y.P.; Yao, Y.; Ning, C.Q.; Guo, Y.J.; Chu, L.F. Fabrication of mesoporous carbonated hydroxyapatite microspheres by hydrothermal method. Mater. Lett. 2011, 65, 2205-2208. [CrossRef]

23. Guo, Y.P.; Yao, Y.B.; Guo, Y.J.; Ning, C.Q. Hydrothermal fabrication of mesoporous carbonated hydroxyapatite microspheres for a drug delivery system. Microporous Mesoporous Mater. 2012, 155, 245-251. [CrossRef]

24. Zhang, C.; Yang, J.; Quan, Z.; Yang, P.; Li, C.; Hou, Z.; Lin, J. Hydroxyapatite nano- and microcrystals with multiform morphologies: Controllable synthesis and luminescence properties. Cryst. Growth Des. 2009, 9, 2725-2733. [CrossRef]

25. Wuthier, R.E.; Rice, G.S.; Wallace, J.E.; Weaver, R.L.; LeGeros, R.Z.; Eanes, E.D. In vitro precipitation of calcium phosphate under intracellular conditions: Formation of brushite from an amorphous precursor in the absence of ATP. Calcif. Tissue Int. 1985, 37, 401-410. [CrossRef] [PubMed]

26. Ren, F.; Leng, Y.; Ding, Y.; Wang, K. Hydrothermal growth of biomimetic carbonated apatite nanoparticles with tunable size, morphology and ultrastructure. Cryst. Eng. Commun. 2013, 15, 2137-2146. [CrossRef]

27. Cao, M.; Wang, Y.; Guo, C.; Qi, Y.; Hu, C. Preparation of ultrahigh-aspect-ratio hydroxyapatite nanofibers in reverse micelles under hydrothermal conditions. Langmuir 2004, 20, 4784-4786. [CrossRef] [PubMed]

28. López-Macipe, A.; Gómez-Morales, J.; Rodríguez-Clemente, R. Nanosized hydroxyapatite precipitation from homogeneous calcium/citrate/phosphate solutions using microwave and conventional heating. Adv. Mater. 1998, 10, 49-53. [CrossRef]

29. Ma, M.G. Hierarchically nanostructured hydroxyapatite: Hydrothermal synthesis, morphology control, growth mechanism, and biological activity. Int. J. Nanomed. 2012, 7, 1781-1791. [CrossRef] [PubMed]

30. Leena, M.; Rana, D.; Webster, T.J.; Ramalingam, M. Accelerated synthesis of biomimetic nano hydroxyapatite using simulated body fluid. Mater. Chem. Phys. 2016, 180, 166-172. [CrossRef]

31. McCaffrey, R.; Long, H.; Jin, Y.; Sanders, A.; Park, W.; Zhang, W. Template Synthesis of gold nanoparticles with an organic molecular cage. J. Am. Chem. Soc. 2014, 136, 1782-1785. [CrossRef] [PubMed]

32. Li, J.L.; Liu, X.Y.; Wang, X.G.; Wang, R.Y. Controlling nanoparticle formation via sizable cages of supramolecular soft materials. Langmuir 2011, 27, 7820-7827. [CrossRef] [PubMed] 
33. Zhang, D.S.; Liu, X.Y.; Li, J.L.; Xu, H.Y.; Lin, H.; Chen, Y.Y. Design and fabrication of a new class of nano hybrid materials based on reactive polymeric molecular cages. Langmuir 2013, 29, 11498-11505. [CrossRef] [PubMed]

34. Liu, Y.; Chi, W.; Zhao, D.; Liu, H.; Deng, Y. Molecular-cage method: An improvement of the precipitation method in synthesizing nanoparticles. Ind. Eng. Chem. Res. 2016, 55, 8403-8408. [CrossRef]

35. Nikpour, R.; Rabiee, S.M.; Jahanshahi, M. Synthesis and characterization of hydroxyapatite/chitosan nanocomposite materials for medical engineering applications. Compos. B Eng. 2012, 43, 1881-1886. [CrossRef]

36. Yamaguchi, I.; Tokuchi, K.; Fukuzaki, H.; Koyama, Y.; Takakuda, K.; Monma, H.; Tanaka, J. Preparation and microstructure analysis of chitosan/hydroxyapatite nanocomposites. J. Biomed. Mater. Res. A. 2000, 55, 20-27. [CrossRef]

37. Song, X.F.; Ling, F.G.; Chen, X.S. Grafting polymerization of L-lactide on the surface of hydroxyapatite nanoparticles. Acta Polym. Sin. 2013, 1, 95-101.

38. Muzzarelli, R.A.A.; Boudrant, J.; Meyer, D.; Manno, N.; Demarchis, M.; Paoletti, M.G. Current views on fungal chitin/chitosan, human chitinases, food preservation, glucans, pectins and inulin: A tribute to Henri Braconnot, precursor of the carbohydrate polymers science, on the chitin bicentennial. Carbohydr. Polym. 2012, 87, 995-1012. [CrossRef]

39. Berger, J.; Reist, M.; Mayer, J.M.; Felt, O.; Gurny, R. Structure and interactions in chitosan hydrogels formed by complexation or aggregation for biomedical applications. Eur. J. Pharm. Biopharm. 2004, 57, 35-52. [CrossRef]

40. Kaya, M.; Baran, T.; Aşan-Özüsağlam, M.; Cakmak, Y.S.; Tozak, K.O.; Mol, A.; Menteş, A.; Sezen, G. Extraction and characterization of chitin and chitosan with antimicrobial and antioxidant activities from cosmopolitan Orthoptera species (Insecta). Biotechnol. Bioproc. Eng. 2015, 20, 168-179. [CrossRef]

41. Kaya, M.; Cakmak, Y.S.; Baran, T.; Asan-Ozusaglam, M.; Mentes, A.; Tozak, K.O. New chitin, chitosan, and O-carboxymethyl chitosan sources from resting eggs of Daphnia longispina (Crustacea); with physicochemical characterization, and antimicrobial and antioxidant activities. Biotechnol. Bioproc. E. 2014, 19, 58-69. [CrossRef]

42. De Souza Costa-Júnior, E.; Pereira, M.M.; Mansur, H.S. Properties and biocompatibility of chitosan films modified by blending with PVA and chemically crosslinked. J. Mater. Sci. Mater. Med. 2009, 20, 553-561. [CrossRef] [PubMed]

43. Liang, P.; Zhao, Y.; Shen, Q.; Wang, D.J.; Xu, D.F. The effect of carboxymethyl-chitosan on the precipitation of calcium carbonate. J. Cryst. Growth 2004, 261, 571-576. [CrossRef]

44. Dumont, V.C.; Mansur, A.A.P.; Carvalho, S.M.; Medeiros Borsagli, F.G.L.; Pereira, M.M.; Mansur, H.S. Chitosan and carboxymethyl-chitosan capping ligands: Effects on the nucleation and growth of hydroxyapatite nanoparticles for producing biocomposite membranes. Mater. Sci. Eng. C 2016, 59, 265-277. [CrossRef] [PubMed]

45. Barna, A.S.; Ciobanu, G.; Luca, C.; Luca, A.C. Nanohydroxyapatite-Calcium fructoborate composites: Synthesis and characterization. Rev. Chim. 2015, 66, 1618-1621.

46. Janicki, P.; Schmidmaier, G. What should be the characteristics of the ideal bone graft substitute? Combining scaffolds with growth factors and/or stem cells. Injury 2011, 42, S77-S81. [CrossRef] [PubMed]

47. Zadegan, S.; Hosainalipour, M.; Rezaie, H.R.; Ghassai, H.; Shokrgozar, M.A. Synthesis and biocompatibility evaluation of cellulose/hydroxyapatite nanocomposite scaffold in 1-n-allyl-3-methyl imidazolium chloride. Mater. Sci. Eng. C 2011, 31, 954-961. [CrossRef]

48. Zimmermann, K.A.; LeBlanc, J.M.; Sheets, K.T.; Fox, R.W.; Gatenholm, P. Biomimetic design of a bacterial cellulose/hydroxyapatite nanocomposite for bone healing applications. Mater. Sci. Eng. C 2011, 31, 43-49. [CrossRef]

49. He, M.; Chang, C.; Peng, N.; Zhang, L. Structure and properties of hydroxyapatite/cellulose nanocomposite films. Carbohyd. Polym. 2012, 87, 2512-2518. [CrossRef]

50. Duarte, E.B.; das Chagas, B.S.; Andrade, F.A.; Brígida, A.I.S.; Borges, M.F.; Muniz, C.R.; Souza Filho, M.S.M.; Morais, J.P.S.; Feitosa, J.P.A.; Rosa, M.F. Production of hydroxyapatite-bacterial cellulose nanocomposites from agroindustrial wastes. Cellulose 2015, 22, 3177-3187. [CrossRef]

51. Wu, J.M.; Liu, R.H. Cost-effective production of bacterial cellulose in static cultures using distillery wastewater. J. Biosci. Bioeng. 2013, 115, 284-290. [CrossRef] [PubMed] 
52. Doshi, J.; Reneker, D.H. Electrospinning process and applications of electrospun fibers. J. Electrost. 1995, 35, 151-160. [CrossRef]

53. Lin, D.Y.; Johnson, M.A.; Vohden, R.A.; Chen, D.; Martin, D.C. Tailored nanofiber morphologies using modulated electrospinning for biomedical applications. Mater. Res. Soc. Symp. Proc. 2003, 736, D3.8.1-D3.8.6. [CrossRef]

54. Crespy, D.; Friedemann, K.; Popa, A.M. Colloid-electrospinning: Fabrication of multicompartment nanofibers by the electrospinning of organic or/and inorganic dispersions and emulsions. Macromol. Rapid Commun. 2012, 33, 1978-1995. [CrossRef] [PubMed]

55. Agarwal, S.; Greiner, A. On the way to clean and safe electrospinning-green electrospinning: Emulsion and suspension electrospinning. Polym. Adv. Technol. 2011, 22, 372-378. [CrossRef]

56. Pal, J.; Sharma, S.; Sanwaria, S.; Kulshreshtha, R.; Nandan, B.; Srivastava, R.K. Conducive 3D porous mesh of poly( $\varepsilon$-caprolactone) made via emulsion electrospinning. Polymer 2014, 55, 3970-3979. [CrossRef]

57. Yang, F.; Both, S.; Yang, X.; Walboomers, X.; Jansen, J. Development of an electrospun nano-apatite/PCL composite membrane for GTR/GBR application. Acta Biomater. 2009, 5, 3295-3304. [CrossRef] [PubMed]

58. Song, X.; Ling, F.; Ma, L.; Yang, C.; Chen, X. Electrospun hydroxyapatite grafted poly(L-lactide)/poly(lactic-co-glycolic acid) nanofibers for guided bone regeneration membrane. Compos. Sci. Technol. 2013, 79, 8-14. [CrossRef]

59. Yang, T.; Cui, X.; Kao, Y.; Wang, H.; Wen, J. Electrospinning PTMC/Gt/OA-HA composite fiber scaffolds and the biocompatibility with mandibular condylar chondrocytes. Colloids Surfaces A 2016, 499, 123-130. [CrossRef]

60. Jeong, S.I.; Ko, E.K.; Yum, J.; Jung, C.H.; Lee, Y.M.; Shin, H. Nanofibrous poly(lactic acid)/hydroxyapatite composite scaffolds for guided tissue regeneration. Macromol. Biosci. 2008, 8, 328-338. [CrossRef] [PubMed]

61. Novotna, K.; Zajdlova, M.; Suchy, T.; Hadraba, D.; Lopot, F.; Zaloudkova, M.; Douglas, T.E.L.; Munzarova, M.; Juklickova, M.; Stranska, D.; et al. Polylactide nanofibers with hydroxyapatite as growth substrates for osteoblast-like cells. J. Biomed. Mater. Res. A 2014, 102, 3918-3930. [CrossRef] [PubMed]

62. Bombonato-Prado, K.F.; Bellesini, L.S.; Junta, C.M.; Marques, M.M.; Passos, G.A.; Rosa, A.L. Microarray-based gene expression analysis of human osteoblasts in response to different biomaterials. J. Biomed. Mater. Res. A 2009, 88, 401-408. [CrossRef] [PubMed]

63. Cooke, M.M.; McCarthy, G.M.; Sallis, J.D.; Morgan, M.P. Phosphocitrate inhibits calcium hydroxyapatite induced mitogenesis and upregulation of matrix metalloproteinase-1, interleukin-1beta and cyclooxygenase-2 mRNA in human breast cancer cell lines. Breast Cancer Res. Treat. 2003, 79, 253-263. [CrossRef] [PubMed]

64. Song, W.; Markel, D.C.; Wang, S.; Shi, T.; Mao, G.; Ren, W. Electrospun polyvinyl alcohol-collagen-hydroxyapatite nanofibers: A biomimetic extracellular matrix for osteoblastic cells. Nanotechnology 2012, 23, 115101. [CrossRef] [PubMed]

65. Long, T.; Liu, Y.T.; Tang, S.; Sun, J.L.; Guo, Y.P.; Zhu, Z.A. Hydrothermal fabrication of hydroxyapatite/chitosan/carbon porous scaffolds for bone tissue engineering. J. Biomed. Mater. Res. B 2014, 102, 1740-1748. [CrossRef] [PubMed]

66. Leszczak, V.; Place, L.W.; Franz, N.; Popat, K.C.; Kipper, M. Nanostructured Biomaterials from Electrospun Demineralized Bone-Matrix: A Survey of Processing and Crosslinking Strategies. J. Appl. Mater. Interfaces 2014, 6, 9328-9337. [CrossRef] [PubMed]

67. Lee, J.H.; Park, J.H.; El-Fiqi, A.; Kim, J.H.; Yun, Y.R.; Jang, J.H.; Han, C.M.; Lee, E.J.; Kim, H.W. Biointerface control of electrospun fiber scaffolds for bone regeneration: Engineered protein link to mineralized surface. Acta Biomater. 2014, 10, 2750-2761. [CrossRef] [PubMed]

68. He, C.; Jin, X.; Ma, P.X. Calcium phosphate deposition rate, structure and osteoconductivity on electrospun poly(L-lactic acid) matrix using electrodeposition or simulated body fluid incubation. Acta Biomater. 2014, 10, 419-427. [CrossRef] [PubMed]

69. Davies, D. Understanding biofilm resistance to antibacterial agents. Nat. Rev. Drug Discov. 2003, 2, 114-122. [CrossRef] [PubMed]

70. Sun, G. Prevention of hospital and community acquired infections by using antibacterial textiles and clothing. In Polymeric Materials with Antimicrobial Activity; Muñoz-Bonilla, A., Cerrada, M.L., Fernández-García, M., Eds.; RSC Polymer Chemistry Series: London, UK, 2013; Chapter 6, pp. 139-155. [CrossRef] 
71. Lenz, A.M.; Fairweather, M.; Cheadle, W.G. Resistance profiles in surgical-site infection. Future Microbiol. 2008, 3, 453-462. [CrossRef] [PubMed]

72. Broex, E.C.; van Asselt, A.D.; Bruggeman, C.A.; van Tiel, F.H. Surgical site infections: How high are the costs? J. Hosp. Infect. 2009, 72, 193-201. [CrossRef] [PubMed]

73. Stamm, W.E. Infections related to medical devices. Ann. Intern. Med. 1978, 89, 764-769. [CrossRef] [PubMed]

74. Zilberman, M.; Elsner, J.J. Antibiotic-eluting medical devices for various applications. J. Control Release 2008, 130, 202-215. [CrossRef] [PubMed]

75. Schnieders, J.; Gbureck, U.; Thull, R.; Kissel, T. Controlled release of gentamicin from calcium phosphate-poly(lactic acid-co-glycolic acid) composite bone cement. Biomaterials 2006, 27, 4239-4249. [CrossRef] [PubMed]

76. Holt, K.B.; Bard, A.J. Interaction of silver(I) ions with the respiratory chain of Escherichia coli: An electrochemical and scanning electrochemical microscopy study of the antimicrobial mechanism of micromolar $\mathrm{Ag}^{+}$. Biochemistry 2005, 44, 13214-13223. [CrossRef] [PubMed]

77. Schreurs, W.J.; Rosenberg, H. Effect of silver ions on transport and retention of phosphate by Escherichia coli. J. Bacteriol. 1982, 152, 7-13. [PubMed]

78. Yang, W.; Shen, C.; Ji, Q.; An, H.; Wang, J.; Liu, Q.; Zhang, Z. Food storage material silver nanoparticles interfere with DNA replication fidelity and bind with DNA. Nanotechnology 2009, 20, 085102. [CrossRef]

79. Kim, J.S.; Kuk, E.; Yu, K.; Kim, J.; Park, S.; Lee, H.; Kim, S.H.; Park, Y.K.; Park, Y.H.; Hwang, C.Y.; et al. Antimicrobial effects of silver nanoparticles. Nanomedicine 2007, 3, 95-101. [CrossRef] [PubMed]

80. Rameshbabu, N.; Sampath Kumar, T.S.; Prabhakar, T.G.; Sastry, V.S.; Murty, K.V.G.K.; Prasad Rao, K. Antibacterial nanosized silver substituted hydroxyapatite: Synthesis and characterization. J. Biomed. Mater. Res. A 2007, 80, 581-591. [CrossRef]

81. Kim, T.N.; Feng, Q.L.; Kim, J.O.; Wu, J.; Wang, H.; Chen, G.C.; Cui, F.Z. Antimicrobial effects of metal ions $\left(\mathrm{Ag}^{+}, \mathrm{Cu}^{2+}, \mathrm{Zn}^{2+}\right)$ in hydroxyapatite. J. Mater. Sci. Mater. Med. 1998, 9, 129-134. [CrossRef] [PubMed]

82. Lim, P.N.; Chang, L.; Thian, E.S. Development of nanosized silver-substituted apatite for biomedical applications: A review. Nanomed. NBM 2015, 11, 1331-1344. [CrossRef] [PubMed]

83. Rauschmann, M.A.; Wichelhaus, T.A.; Stirnal, V.; Dingeldein, E.; Zichner, L.; Schnettler, R.; Alt, V. Nanocrystalline hydroxyapatite and calcium sulphate as biodegradable composite carrier material for local delivery of antibiotics in bone infections. Biomaterials 2005, 26, 2677-2684. [CrossRef] [PubMed]

84. Xiong, Z.C.; Zhu, Y.J.; Chen, F.F.; Sun, T.W.; Shen, Y.Q. One-step synthesis of silver nanoparticle-decorated hydroxyapatite nanowires for the construction of highly flexible free-standing paper with high antibacterial activity. Chemistry 2016, 22, 11224-11231. [CrossRef] [PubMed]

85. Livitska, O.; Struynska, N.; Zatovsky, I.; Nikolenko, I.; Slobodyanik, N.; Prylutskyy, Y.; Epple, M.; Prymak, O.; Byeda, A. Copper(II), zinc(II) and copper(II)/zinc(II)-containing carbonate-substituted hydroxyapatite: Synthesis, characterization and thermal behaviour. Mater. Werkstofftech. 2016, 47, 85-91. [CrossRef]

86. Shannmugam, S.; Gopal, B. Copper substituted hydroxyapatite and fluorapatite; Synthesis, characterization and antimicrobial properties. Ceram. Int. 2014, 40, 15655-15662. [CrossRef]

87. Niu, N.; Wang, D.; Huang, S.; Li, C.; He, F.; Gai, S.; Li, X.; Yang, P. Controlled synthesis of luminescent F-substituted strontium hydroxyapatite with hierarchical structures for drug delivery. Cryst. Eng. Commun. 2012, 14, 1744-1752. [CrossRef]

88. Xu, Z.; Li, C.; Hou, Z.; Yang, D.; Kang, X.; Lin, J. Facile synthesis of an up-conversion luminescent and mesoporous $\mathrm{Gd}_{2} \mathrm{O}_{3}$ : $\mathrm{Er}^{3+} @ \mathrm{nSiO}_{2} @ \mathrm{mSiO}_{2}$ nanocomposite as a drug carrier. Nanoscale 2011, 3, 661-667. [CrossRef] [PubMed]

89. Guo, R.; Li, L.L.; Zhao, W.H.; Chen, Y.X.; Wang, X.; Fang, C.J.; Feng, W.; Zhang, T.L.; Lu, M.; Peng, S.; et al. The intracellular controlled release from bioresponsive mesoporous silica with folate as both targeting and capping agent. Nanoscale 2012, 4, 3577-3583. [CrossRef] [PubMed]

90. Wang, X.; Zhuang, J.; Peng, Q.; Li, Y. A general strategy for nanocrystal synthesis. Nature 2005, 437, $121-124$. [CrossRef] [PubMed]

91. Heng, C.; Zheng, X.; Liu, M.; Xu, D.; Huang, H.; Deng, F.; Hui, J.; Zhang, X.; Wei, Y. Fabrication of luminescent hydroxyapatite nanorods through surface-initiated RAFT polymerization: Characterization, biological imaging and drug delivery applications. Appl. Surface Sci. 2016, 386, 269-275. [CrossRef]

92. Hui, J.; Wang, X. Hydroxyapatite nanocrystals: Colloidal chemistry, assembly and their biological applications. Inorg. Chem. Front. 2014, 1, 215-225. [CrossRef] 
93. Hui, J.; Zhang, X.; Zhang, Z.; Wang, S.; Tao, L.; Wei, Y.; Wang, X. Fluoridated HAp:Ln ${ }^{3+}(\mathrm{Ln}=\mathrm{Eu}$ or Tb) nanoparticles for cell-imaging. Nanoscale 2012, 4, 6967-6970. [CrossRef]

94. Zheng, X.; Liu, M.; Hui, J.; Fan, D.; Ma, H.; Zhang, X.; Wang, Y.; Wei, Y. $\mathrm{Ln}^{3+}$-doped hydroxyapatite nanocrystals: Controllable synthesis and cell imaging. Phys. Chem. Chem. Phys. 2015, 17, 20301-20307. [CrossRef] [PubMed]

95. Zhang, X.; Hui, J.; Yang, B.; Yang, Y.; Fan, D.; Liu, M.; Tao, L.; Wei, Y. PEGylation of fluoridated hydroxyapatite (FAp): $\mathrm{Ln}^{3+}$ nanorods for cell imaging. Polym. Chem. 2013, 4, 4120-4125. [CrossRef]

96. Chatterjee, D.K.; Rufaihah, A.J.; Zhang, Y. Upconversion fluorescence imaging of cells and small animals using lanthanide doped nanocrystals. Biomaterials 2008, 29, 937-943. [CrossRef] [PubMed]

97. Zhang, X.; Wang, K.; Liu, M.; Zhang, X.; Tao, L.; Chen, Y.; Wei, Y. Polymeric AIE-based nanoprobes for biomedical applications: Recent advances and perspectives. Nanoscale 2015, 7, 11486-11508. [CrossRef] [PubMed]

98. Li, D.; Liang, Z.; Chen, J.; Yu, J.; Xu, R. AIE luminogen bridged hollow hydroxyapatite nanocapsules for drug delivery. Dalton Trans. 2013, 42, 9877-9883. [CrossRef] [PubMed]

99. Hahn, M.A.; Singh, A.K.; Sharma, P.; Brown, S.C.; Moudgil, B.M. Nanoparticles as contrast agents for in vivo bioimaging: Current status and future perspectives. Anal. Bioanal. Chem. 2011, 399, 3-27. [CrossRef] [PubMed]

100. Pankhurst, Q.A.; Connolly, J.; Jones, S.; Dobson, J. Applications of magnetic nanoparticles in biomedicine. J. Phys. D Appl. Phys. 2003, 36, R167. [CrossRef]

101. Fukumori, Y.; Ichikawa, H. Nanoparticles for cancer therapy and diagnosis. Adv. Powder Technol. 2006, 17, 1-28. [CrossRef]

102. Laranjeira, M.S.; Moço, A.; Ferreira, J.; Coimbra, S.; Costa, E.; Santos-Silva, A.; Ferreira, P.J.; Monteiro, F.J. Different hydroxyapatite magnetic nanoparticles for medical imaging: Its effects on hemostatic, hemolytic activity and cellular cytotoxicity. Colloid Surface B 2016, 146, 363-374. [CrossRef] [PubMed]

103. Panseri, S.; Cunha, C.; D’Alessandro, T.; Sandri, M.; Russo, A.; Giavaresi, G.; Marcacci, M.; Hung, C.T.; Tampieri, A. Magnetic hydroxyapatite bone substitutes to enhance tissue regeneration: Evaluation in vitro using osteoblast-like cells and in vivo in a bone defect. PLoS ONE 2012, 7, e38710. [CrossRef] [PubMed]

104. Inukai, A.; Sakamoto, N.; Aono, H.; Sakurai, O.; Shinozaki, K.; Suzuki, H.; Wakiya, N. Synthesis and hyperthermia property of hydroxyapatite-ferrite hybrid particles by ultrasonic spray pyrolysis. J. Magn. Magn. Mater. 2011, 323, 965-969. [CrossRef]

105. Aval, N.A.; Islamian, J.P.; Hatamian, M.; Arabfirouzjaei, M.; Javadpour, J.; Rashidi, M.R. Doxorubicin loaded large-pore mesoporous hydroxyapatite coated superparamagnetic $\mathrm{Fe}_{3} \mathrm{O}_{4}$ nanoparticles for cancer treatment. Int. J. Pharm. 2016, 509, 159-167. [CrossRef] [PubMed]

106. Shekhar, S.; Roy, A.; Hong, D.; Kumta, P.N. Nanostructured silicate substituted calcium phosphate (NanoSiCaPs) nanoparticles-Efficient calcium phosphate based non-viral gene delivery systems. Mater. Sci. Eng. C Mater. Biol. Appl. 2016, 69, 486-495. [CrossRef] [PubMed]

107. Truong-Le, V.L.; Walsh, S.M.; Schwabert, E.; Mao, H.Q.; Guggino, W.B.; August, J.T.; Leong, K.W. Gene transfer by DNA-gelatin nanospheres. Arch. Biochem. Biophys. 1999, 361, 47-56. [CrossRef] [PubMed]

108. Orrantia, E.; Chang, P.L. Intracellular-distribution of DNA internalized through calcium-phosphate precipitation. Exp. Cell Res. 1990, 190, 170-174. [CrossRef]

109. James, R.F.L.; Grosveld, F.G. DNA-mediated gene transfer into mammalian cells. In Techniques in Molecular Biology; Walker, J.M., Gaastra, W., Eds.; Croom Helm: London, UK, 1987; Volume 2, pp. 187-202.

110. Roy, I.; Mitra, S.; Maitra, A.; Mozumdar, S. Calcium phosphate nanoparticles as novel non-viral vectors for targeted gene delivery. Int. J. Pharm. 2003, 250, 25-33. [CrossRef]

111. Bisht, S.; Bhakta, G.; Mitra, S.; Maitra, A. pDNA loaded calcium phosphate nanoparticles: Highly efficient non-viral vector for gene delivery. Int. J. Pharm. 2005, 288, 157-168. [CrossRef]

112. Rejman, J.; Oberle, V.; Zuhorn, I.S.; Hoekstra, D. Size-dependent internalization of particles via the pathways of clathrin- and caveolae-mediated endocytosis. Biochem. J. 2004, 377, 159-169. [CrossRef] [PubMed]

113. Luo, D.; Saltzmann, W.M. Synthetic DNA delivery systems. Nat. Biotechnol. 2000, 18, 33-37. [PubMed]

114. Lee, K.; Oh, M.H.; Lee, M.S.; Nam, Y.S.; Park, T.G.; Jeong, J.H. Stabilized calcium phosphate nano-aggregates using a dopa-chitosan conjugate for gene delivery. Int. J. Pharm. 2013, 445, 196-202. [CrossRef] [PubMed] 
115. Chowdhury, E.H.; Kunou, M.; Nagaoka, M.; Kundu, A.K.; Hoshiba, T.; Akaike, T. High-efficiency gene delivery for expression in mammalian cells by nanoprecipitates of Ca-Mg phosphate. Gene 2004, 341, 77-82. [CrossRef] [PubMed]

116. Chowdhury, E.H. Fluoride enhances transfection activity of carbonate apatite by increasing cytoplasmic stability of plasmid DNA. Biochem. Biophys. Res. Commun. 2011, 409, 745-747. [CrossRef] [PubMed]

117. Hanifi, A.; Fathi, M.H.; Sadeghi, H.M.M. Effect of strontium ions substitution on gene delivery related properties of calcium phosphate nanoparticles. J. Mater. Sci. Mater. Med. 2010, 21, 2601-2609. [CrossRef] [PubMed]

118. Hing, K.A.; Revell, P.A.; Smith, N.; Buckland, T. Effect of silicon level on rate, quality and progression of bone healing within silicate-substituted porous hydroxyapatite scaffolds. Biomaterials 2006, 27, 5014-5026. [CrossRef] [PubMed]

119. Porter, A.E.; Patel, N.; Skepper, J.N.; Best, S.M.; Bonfield, S.M.W. Comparison of in vivo dissolution processes in hydroxyapatite and silicon-substituted hydroxyapatite bioceramics. Biomaterials 2003, 24, 4609-4620. [CrossRef]

120. Marchat, D.; Zymelka, M.; Coelho, C.; Gremillard, L.; Joly-Pottuz, L.; Babonneau, F.; Esnouf, C.; Chevalier, J.; Bernache-Assollant, D. Accurate characterization of pure silicon-substituted hydroxyapatite powders synthesized by a new precipitation route. Acta Biomater. 2013, 9, 6992-7004. [CrossRef] [PubMed]

121. Sokolova, V.; Prymak, O.; Meyer-Zaika, W.; Cölfen, H.; Rehage, H.; Shukla, A.; Epple, M. Synthesis and characterisation of DNA-functionalised calcium phosphate nanoparticles. Mater. Werkstofftech. 2006, 37, 441-445. [CrossRef]

122. Tenkumo, T.; Rotan, O.; Sokolova, V.; Epple, M. Protamine increases transfection efficiency and cell viability after transfection with calcium phosphate nanoparticles. Nano Biomed. 2013, 5, 64-74.

123. Tenkumo, T.; Vanegas Sáenz, J.R.; Takada, Y.; Takahashi, M.; Rotan, O.; Sokolova, V.; Epple, M.; Sasaki, K. Gene transfection of human mesenchymal stem cells with a nano-hydroxyapatite-collagen scaffold containing DNA-functionalized calcium phosphate nanoparticles. Genes Cells 2016, 21, 682-695. [CrossRef] [PubMed]

124. Revilla-López, G.; Casanovas, J.; Bertran, O.; Turon, P.; Puiggalí, J.; Alemán, C. Modeling biominerals formed by apatites and DNA. Biointerphases 2013, 8, 10. [CrossRef] [PubMed]

125. Turon, P.; del Valle, L.J.; Alemán, C.; Puiggalí, J. Preparation and applications of hydroxyapatite nanocomposites based on biodebradable and natural polymers. In Synthesis Techniques for Polymer Nanocomposites; Mittal, V., Ed.; Wiley-VCH: Weinheim, Germany, 2015; pp. 51-85.

126. Bertran, O.; del Valle, L.J.; Revilla-López, G.; Chaves, G.; Cardús, L.; Casas, M.T.; Casanovas, J.; Turon, P.; Puiggalí, J.; Alemán, C. Mineralization of DNA into nanoparticles of hydroxyapatite. Dalton Trans. 2014, 43, 317-327. [CrossRef] [PubMed]

127. Del Valle, L.J.; Bertran, O.; Chaves, G.; Revilla-López, G.; Rivas, M.; Casas, M.T.; Casanovas, J.; Turon, P.; Puiggalí, J.; Alemán, C. DNA adsorbed on hydroxyapatite surfaces. J. Mater. Chem. B 2014, 2, 6953-6966. [CrossRef]

128. Wang, L.; Nancollas, G.H. Calcium orthophosphates: Crystallization and dissolution. Chem. Rev. 2008, 108, 4628-4669. [CrossRef] [PubMed]

129. Dorozhkin, V. Dissolution mechanism of calcium apatites in acids: A review of literature. World J. Methodol. 2012, 2, 1-17. [CrossRef] [PubMed]

130. Bertran, O.; Revilla-López, G.; Casanovas, J.; del Valle, L.J.; Turon, P.; Puiggalí, J.; Alemán, C. Dissolving hydroxyolite: A DNA molecule into its hydroxyapatite mold. Chem. Eur. J. 2016, 22, 6631-6636. [CrossRef] [PubMed]

131. Turon, P.; Puiggalí, J.; Bertran, O.; Alemán, C. Surviving mass extinctions through biomineralized DNA. Chem. Eur J. 2015, 21, 18892-18898. [CrossRef] [PubMed]

132. Wang, F.K.; Cao, B.R.; Mao, C.B. Bacteriophage bundles with prealigned $\mathrm{Ca}^{2+}$ initiate the oriented nucleation and growth of hydroxylapatite. Chem. Mater. 2010, 22, 3630-3636. [CrossRef] [PubMed]

133. He, T.; Abbineni, G.; Cao, B.R.; Mao, C.B. Nanofibrous bio-inorganic hybrid structures formed through self-assembly and oriented mineralization of genetically engineered phage nanofibers. Small 2010, 6, 2230-2235. [CrossRef] [PubMed]

134. Cao, B.; Yang, M.; Mao, C. Phage as a genetically modifiable supramacromolecule in chemistry, materials and medicine. Acc. Chem. Res. 2016, 49, 1111-1120. [CrossRef] 
135. Xu, H.; Cao, B.R.; George, A.; Mao, C.B. Self-assembly and mineralization of genetically modifiable biological nanofibers driven by $\beta$-structure formation. Biomacromolecules 2011, 12, 2193-2199. [CrossRef] [PubMed]

136. Wang, S.S.; Chao, H.S.; Liu, H.L.; Liu, H.S. Stability of hen egg white lysozyme during denaturation is enhanced by pretreatment with supercritical carbon dioxide. J. Biosci. Bioeng. 2009, 107, 355-359. [CrossRef] [PubMed]

137. Xu, M.; Arulandu, A.; Struck, D.K.; Swanson, S.; Sacchettini, J.C.; Young, R. Disulfide isomerization after membrane release of its SAR domain activates P1 lysozyme. Science 2005, 307, 113-117. [CrossRef] [PubMed]

138. Cai, C.; Bakowsky, U.; Rytting, E.; Schaper, A.K.; Kissel, T. Charged nanoparticles as protein delivery systems: A feasibility study using lysozyme as model protein. Eur. J. Pharm. Biopharm. 2008, 69, 31-42. [CrossRef] [PubMed]

139. Nagadome, H.; Kawano, K.; Terada, Y. Identification of the adsorbing site of lysozyme onto the hydroxyapatite surface using hydrogen exchange and ${ }^{1} \mathrm{H}-\mathrm{NMR}$. FEBS Lett. 1993, 317, 128-130. [CrossRef]

140. Wang, Y.; Hao, H.; Zhang, S. Lysozyme loading and release from Se doped hydroxyapatite nanoparticles. Mater. Sci. Eng. C 2016, 61, 545-552. [CrossRef]

141. Ishihara, S.; Matsumoto, T.; Onoki, T.; Uddin, M.H.; Sohmura, T.; Nakahira, A. Regulation of the protein-loading capacity of hydroxyapatite by mercaptosuccinic acid modification. Acta Biomater. 2010, 6, 830-835. [CrossRef] [PubMed]

142. Lee, W.H.; Loo, C.Y.; Van, K.L.; Zavgorodniy, A.V.; Rohanizadeh, R. Modulating protein adsorption onto hydroxyapatite particles using different amino acid treatments. J. R. Soc. Interface 2012, 9, 918-927. [CrossRef] [PubMed]

143. Lee, W.H.; Loo, C.Y.; Zavgorodniy, A.V.; Ghadiri, M.; Rohanizadeh, R. A novel approach to enhance protein adsorption and cell proliferation on hydroxyapatite: Citric acid treatment. RSC Adv. 2013, 3, 4040-4051. [CrossRef]

144. Ma, Y.; Zhang, J.; Guo, S.; Shi, J.; Du, W.; Wang, Z.; Ye, L.; Gu, W. Biomimetic mineralization of nano-sized, needle-like hydroxyapatite with ultrahigh capacity for lysozyme adsorption. Mater. Sci. Eng. C 2016, 68, 551-556. [CrossRef] [PubMed]

145. Chang, Y.; Shu, S.H.; Shih, Y.J.; Chu, C.W.; Ruaan, R.C.; Chen, W.Y. Hemocompatible mixed-charge copolymer brushes of pseudozwitterionic surfaces resistant to nonspecific plasma protein fouling. Langmuir 2010, 26, 3522-3530. [CrossRef] [PubMed]

146. Matsumoto, T.; Okazaki, M.; Inoue, M.; Hamada, Y.; Taira, M.; Takahashi, J. Crystallinity and solubility characteristics of hydroxyapatite adsorbed amino acid. Biomaterials 2002, 23, 2241-2247. [CrossRef]

147. Heiss, A.; DuChesne, A.; Denecke, B.; Grötzinger, J.; Yamamoto, J.K.; Renné, T.; Jahnen-Dechent, W. A structural basis of calcification inhibition by alpha(2)-HS glycoprotein/fetuin-A-Formation of colloidal calciprotein particles. J. Biol. Chem. 2003, 278, 13333-13341. [CrossRef] [PubMed]

148. Thomas, S.C.; Harshita, Mishra P.K.; Talegaonkar, S. Ceramic nanoparticles: Fabrication methods and applications in drug delivery. Curr. Pharm. Des. 2015, 21, 6165-6188. [CrossRef] [PubMed]

149. Thomas, S.C.; Sharma, H.; Rawat, P.; Verma, A.; Leekha, A.; Kumar, V.; Tyagi, A.; Gurjar, B.S.; Iqbal, Z.; Talegaonkar, S. Synergistic anticancer efficacy of bendamustine hydrochloride loaded bioactive hydroxyapatite nanoparticles: In-vitro, ex-vivo and in-vivo evaluation. Colloids Surf. B Biointerface 2016, 146, 852-860. [CrossRef] [PubMed]

150. Vallet-Regí, M.; Balas, F.; Arcos, D. Mesoporous materials for drug delivery. Angew. Chem. Int. Ed. 2007, 46, 7548-7558. [CrossRef] [PubMed]

151. Xu, Q.; Tanaka, Y.; Czernuszka, J.T. Encapsulation and release of a hydrophobic drug from hydroxyapatite coated liposomes. Biomaterials 2007, 28, 2687-2694. [CrossRef] [PubMed]

152. Leu, C.T.; Luegmayr, E.; Freedman, L.P.; Rodan, G.A.; Reszka, A.A. Relative binding affinities of bisphosphonates for human bone and relationship to antiresorptive efficacy. Bone 2006, 38, 628-636. [CrossRef] [PubMed]

153. Hwang, S.J.; Lee, J.S.; Ryu, T.K.; Kang, R.H.; Jeong, K.Y.; Jun, D.R.; Koh, J.M.; Kim, S.E.; Choi, S.W. Alendronate-modified hydroxyapatite nanoparticles for bone-specific dual delivery of drug and bone mineral. Macromol. Res. 2016, 24, 623-628. [CrossRef]

154. Liang, Y.H.; Liu, C.H.; Liao, S.H.; Lin, Y.Y.; Tang, H.W.; Liu, S.Y.; Lai, I.R.; Wu, K.C. Cosynthesis of cargo-loaded hydroxyapatite/alginate core-shell nanoparticles (HAP@Alg) as pH-responsive nanovehicles by a pre-gel method. ACS Appl. Mater. Interfaces 2012, 4, 6720-6727. [CrossRef] [PubMed] 
155. Tang, W.; Yuan, Y.; Liu, C.; Wu, Y.; Lu, X.; Qian, J. Differential cytotoxicity and particle action of hydroxyapatite nanoparticles in human cancer cells. Nanomedicine 2014, 9, 397-412. [CrossRef] [PubMed]

156. Han, Y.; Li, S.; Cao, X.; Yuan, L.; Wang, Y.; Yin, Y.; Qiu, T.; Dai, H.; Wang, X. Different inhibitory effect and mechanism of hydroxyapatite nanoparticles on normal cells and cancer cells in vitro and in vivo. Sci. Rep. 2014, 4, 7134. [CrossRef] [PubMed]

157. Liu, Z.S.; Tang, S.L.; Ai, Z.L. Effects of hydroxyapatite nanoparticles on proliferation and apoptosis of human hepatoma BEL-7402 cells. World J. Gastroenterol. 2003, 9, 1968-1971. [CrossRef] [PubMed]

158. Li, B.; Guo, B.; Fan, H.S.; Zhang, X.D. Preparation of nano-hydroxyapatite particles with different morphology and their response to highly malignant melanoma cells in vitro. Appl. Surf. Sci. 2008, 255, 357-360. [CrossRef]

159. Yuan, Y.; Liu, C.; Qian, J.; Wang, J.; Zhang, Y. Size-mediated cytotoxicity and apoptosis of hydroxyapatite nanoparticles in human hepatoma HepG2 cells. Biomaterials 2010, 31, 730-740. [CrossRef] [PubMed]

160. Yang, L.; Wu, S.H.; Zhang, Q.H.; Liu, F.Y.; Wu, P. 23,24-Dihydrocucurbitacin B induces G2/M cell-cycle arrest and mitochondria-dependent apoptosis in human breast cancer cells (Bcap37). Cancer Lett. 2007, 256, 267-278. [CrossRef] [PubMed]

161. Cui, X.; Liang, T.; Liu, C.; Yuan, Y.; Qian, J. Correlation of particle properties with cytotoxicity and cellular uptake of hydroxyapatite nanoparticles in human gastric cancer cells. Mater. Sci. Eng. C 2016, 67, 453-460. [CrossRef] [PubMed]

162. Venkatesan, P.; Puvvada, N.; Dash, R.; Prashanth Kumar, B.N.; Sarkar, D.; Azab, B.; Pathak, A.; Kundu, S.C.; Fisher, P.B.; et al. The potential of celecoxib-loaded hydroxyapatite-chitosan nanocomposite for the treatment of colon cancer. Biomaterials 2011, 32, 3794-3806. [CrossRef] [PubMed]

163. Maeda, H.; Wu, J.; Sawa, T.; Matsumura, Y.; Hori, K. Tumor vascular permeability and the EPR effect in macromolecular therapeutics: A review. J. Control Release 2000, 65, 271-284. [CrossRef]

164. Yang, H.C.; Hon, M.H. The effect of the molecular weight of chitosan nanoparticles and its application on drug delivery. Microchem. J. 2009, 92, 87-91. [CrossRef]

165. Li, F.; Li, J.; Wen, X.; Zhou, S.; Tong, X.; Su, P.; Li, H.; Shi, D. Anti-tumor activity of paclitaxel-loaded chitosan nanoparticles: An in vitro study. Mater. Sci. Eng. C 2009, 29, 2392-2397. [CrossRef]

166. Victor, S.P.; Paul, W.; Vineeth, V.M.; Komeri, R.; Jayabalan, M.; Sharma, C.P. Neodymium doped hydroxyapatite theranostic nanoplatforms for colon specific drug delivery applications. Colloid. Surf. B Biointerfaces 2016, 145, 539-547. [CrossRef] [PubMed]

167. Zöller, M. CD44: Can a cancer-initiating cell profit from an abundantly expressed molecule? Nat. Rev. Cancer 2011, 11, 254-267. [CrossRef] [PubMed]

168. Xiong, H.; Du, S.; Ni, J.; Zhou, J.; Yao, J. Mitochondria and nuclei dual-targeted heterogeneous hydroxyapatite nanoparticles for enhancing therapeutic efficacy of doxorubicin. Biomaterials 2016, 94, 70-83. [CrossRef] [PubMed]

169. Robertson, C.A.; Evans, D.H.; Abrahamse, H. Photodynamic therapy (PDT): A short review on cellular mechanisms and cancer research applications for PDT. J. Photochem. Photobiol. B 2009, 96, 1-8. [CrossRef] [PubMed]

170. Klein, S.; Dell'Arciprete, M.L.; Wegmann, M.; Distel, L.V.; Neuhuber, W.; Gonzalez, M.C.; Kryschi, C. Oxidized silicon nanoparticles for radiosensitization of cancer and tissue cells. Biochem. Biophys. Res. Commun. 2013, 434, 217-222. [CrossRef] [PubMed]

171. Kwatra, D.; Venugopal, A.; Anant, S. Nanoparticles in radiation therapy: A summary of various approaches to enhance radiosensitization in cancer. Transl. Cancer Res. 2013, 2, 330-342.

172. Matusiewicz, H. Potential release of in vivo trace metals from metallic medical implants in the human body: From ions to nanoparticles-A systematic analytical review. Acta Biomater. 2014, 10, 2379-2403. [CrossRef] [PubMed]

173. Chen, M.H.; Hanagata, N.; Ikoma, T.; Huang, J.Y.; Li, K.Y.; Lin, C.P.; Lin, F.H. Hafnium-doped hydroxyapatite nanoparticles with ionizing radiation for lung cancer treatment. Acta Biomater. 2016, 37, 165-173. [CrossRef] [PubMed]

(C) 2017 by the authors; licensee MDPI, Basel, Switzerland. This article is an open access article distributed under the terms and conditions of the Creative Commons Attribution (CC-BY) license (http:/ / creativecommons.org/licenses/by/4.0/). 